\title{
Variable style of transition between Palaeogene fluvial fan and lacustrine systems, southern Pyrenean foreland, NE Spain
}

\author{
ALBERT@ SÁEZ* PERE ANADÓN†, MARÍA J. HERRERの* and ANDREA MOSCARIELLO

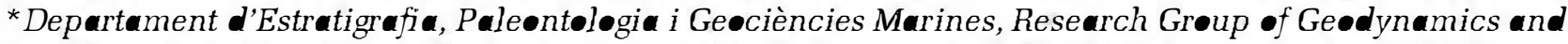 \\ Basin Analysis, Facultat de Geølogia, Universitat de Barcelona, Calle Martí Franqués s/n, E-08028 \\ Barcelona, Spain (E-mail: a.saez@ub.edu) \\ $\dagger$ †nstitut de Ciències de la Terra 'I. Almera', C.S.I.C. Calle L. Sølé Sabarís s/n, E-øsozs Barcelona, Spain \\ ¥Shell International Exploration and Production B.V. Kesslerpark 1, $228 \mathrm{~s}$ GD Rijswijk-ZH, The \\ Netherlands
}

\begin{abstract}
Two Palaeogene fluvial fan systems linked to the south-Pyrenean margin are recognized in the eastern Ebro Basin: the Cardona-Súria and Solsona-Sana üja fans. These had radii of 40 and $35 \mathrm{~km}$ and were 800 and $600 \mathrm{~km}^{2}$ in area respectively. During the Priabonian to the Middle Rupelian, the fluvial fans built into a hydrologically closed foreland basin, and shallow lacustrine systems persisted in the basin centre. In the studied area, both fans are part of the same upward-coarsening megasequence (up to $\mathbf{8 0 0} \mathrm{m}$ thick), driven by hinterland drainage expansion and foreland propagation of Pyrenean thrusts. Fourteen sedimentary facies have been grouped into seven facies associations corresponding to medial fluvial fan, channelized terminal lobe, nonchannelized terminal lobe, mudflat, deltaic, evaporitic playa-lake and carbonate-rich, shallow lacustrine environments. Lateral correlations define two styles of alluvial-lacustrine transition. During low lake-level stages, terminal lobes developed, whereas during lake highstands, fluvial-dominated deltas and interdistributary bays were formed. Terminal lobe deposits are characterized by extensive (100-600 $\mathrm{m}$ wide) sheet-like fine sandstone beds formed by sub-aqueous, quasi-steady, hyperpycnal turbidity currents. Sedimentary structures and trace fossils indicate rapid desiccation and subaerial exposure of the lobe deposits. These deposits are arranged in coarsening-fining sequences (metres to tens of metres in thickness) controlled by a combination of tectonics, climatic oscillations and autocyclic sedimentary processes. The presence of anomalously deeply incised distributary channels associated with distal terminal lobe or mudflat deposits indicates rapid lake-level falls. Deltaic deposits form progradational coarsening-upward sequences (several metres thick) characterized by channel and friction-dominated mouth-bar facies overlying white-grey offshore lacustrine facies. Deltaic bar deposits are less extensive $(50-300 \mathrm{~m}$ wide) than the terminal lobes and were also deposited by hyperpycnal currents, although they lack evidence of emergence. Sandy deltaic deposits accumulated locally at the mouths of main feeder distal fan streams and were separated by muddy interdistributary bays; whereas the terminal lobe sheets expand from a series of mid-fan intersection points and coalesced to form a more continuous sandy fan fringe.
\end{abstract}

Keywords Delta, distal fluvial fan, Ebro Basin, hyperpycnites, terminal lobe, trace fossils. 


\section{INTRODUCTION}

Large fluvial fan systems are common in foreland settings adjacent to active mountain belts (Anadón et al., 1985; DeCelles \& Giles, 1996; Hovius, 1996; Nichols \& Hirst, 1998; López-Blanco et al., 2000; Jones, 2004; Yuste et al., 2004; Luzón, 2005; Nichols \& Thompson, 2005) where they often pass laterally into hydrologically open or closed lacustrine systems in the foredeep basin. The interrelation between the fans and lakes is complex, particularly in closed basins, because the lake level is very sensitive to climate (Anadón et al., 1989; Kelly, 1993; Sadler \& Kelly, 1993; Hinds et al., 2004) and the interaction between fan and lake processes, and the resulting facies architecture, are poorly understood.

Fluvial fans (or meg ans of Gohain \& Parkash, 1990) were defined by Collinson (1996) as large fans characterized by the migration of permanent or intermittent channelized streams. Channel shifting is largely random, and related to crevassing and the development and abandonment of channel bars. In this paper, the term fluvial fan is used to describe large $\left(10^{2}-10^{3} \mathrm{~km}^{2}\right)$, low gradient, fan-shaped sediment accumulations formed mostly by fluvial deposits (Moscariello, 2005). Usually, these are associated with large catchments draining mountain ranges. By contrast, alluvial fans are usually smaller in size (commonly $\leq 100 \mathrm{~km}^{2}$ ), have local catchments and steeper slopes, and may involve significant gravity-flow processes (Blair \& McPherson, 1994). Fluvial fans may be fringed in their distal parts by a variety of other non-marine alluvial or lacustrine environments. The facies and sequential arrangement of distal-alluvial systems have been described in ancient extensional settings (Hubert \& Hyde, 1982; George \& Berry, 1993; Mack et al., 1997; Hornung \& Aigner, 2002a,b) and in recent and ancient foreland and back-arc basins (Tunbridge, 1984; DeCelles \& Cavazza, 1999; Newell et al., 1999; Horton \& DeCelles, 2001; Shukla et al., 2001; Zavala et al., 2006). Modern sedimentary processes in distal-alluvial environments in dryland areas have been described by Mukerji (1976), Friend (1978), Parkash et al. (1983), Sneh (1983), Abdullatif (1989), Kelly \& Olsen (1993) and Croke et al. (1996). Kelly \& Olsen (1993) introduced the term terminal fan for the whole fan system in situations where the water discharged across the fan surface was lost to infiltration and evaporation. In this paper, the term terminal lobe is used to identify the distal part of a larger fan - akin to a distal secondary fan lobe - interfingering with standing bodies of water or mudflat deposits (e.g. George \& Berry, 1993; Hinds et al., 2004). These sub-environments display a complex fan-like distributarystream pattern dominated by sheet sandstones which are formed from frontal splays built by flash discharge in front of distributary channels. In this definition, deltaic settings are not included in the terminal lobe environment.

An appropriate modern analogue for the distal fluvial and lacustrine systems described in this paper is the marginal areas of Lake Eyre, Australia, described by Lang et al. (2004). These authors discuss the detailed bed geometries and lateral relationships between sub-environments and refer to the distal fluvial deposits as fluvial-lacustrine deltas and terminal splays, the latter being equivalent to the definition of terminal lobes followed here. Despite work by Lang et al. (2004) and the sedimentary processes described also by Tooth (1999a,b), Magee et al. (1995) and Croke et al. (1996), no detailed studies of thick and well-exposed distal fluvial fan sequences and the lateral and vertical relationships between distal fluvial and lacustrine facies have been discussed in the literature. To fill this gap, a sedimentological and stratigraphical study was carried out on the Tertiary continental fill of the eastern Ebro Basin, Spain. The present-day geomorphology of this area reflects a history of Alpine uplift and subsequent river entrenchment, resulting in extensive outcrops that make this area an ideal location for three-dimensional sedimentological and architectural studies.

The aims of this paper are to: (i) describe and analyse the distal deposits of two contrasting Palaeogene fluvial fan systems developed in the eastern Ebro Basin; (ii) characterize the relationships between the fluvial fan deposits and the deposits from shallow, hydrologically closed lacustrine systems that developed in the centre of the basin; and (iii) provide an interpretative model to aid the understanding of the evolution of fluvial fan systems with particular emphasis on the relationship between terminal lobes, deltas and coeval lacustrine systems.

\section{GEOLOGICAL SETTING}

The Ebro Basin (Fig. 1) represents the autochthonous part of the southern foreland sedimentary basin-complex flanking the Pyrenees, and developed in response to south-verging thrust systems during the Upper Cretaceous - Palaeogene. To the 
SW, the south-Pyrenean foreland basin is bounded by the Iberian Range and by the Catalan Coastal Ranges to the SE (Fig. 1). During the Palaeogene, ca. $100 \mathrm{~km}$ of southward displacement took place on the Pyrenean thrust front (Muñoz, 1992).

In the Late Eocene, a widespread marine regression and the tectonic restriction of the basin resulted in the deposition of marine evaporites that are up to $300 \mathrm{~m}$ thick (the Cardona Formation). From the Late Eocene to the Miocene, the Ebro Basin was characterized by internal drainage. In this non-marine basin, marginal alluvial systems and central shallow lacustrine and mudflat environments developed. In the basin centre, several major lacustrine expansion-contraction cycles, each lasting ca. 2 Myr, occurred (Anadón et al., 1989). In the eastern Ebro Basin, the marginal alluvial deposits correspond to: (i) a set of low gradient fluvial fans, $500-1500 \mathrm{~km}^{2}$ in area, derived both from the Pyrenees (including the Súria-Cardona and Solsona-Sanaiija fans) and the Catalan Coastal Ranges (including the Manresa-Igualada fan), and from the Iberian Range (Fig. 1A). These fluvial fans were fed by relatively large drainage areas, and entered lacustrine systems distally; (ii) smaller, high gradient alluvial fans which were fed by local drainage areas, directly from the mountain fronts, lateral to the fluvial fans and consisting mainly of massflow conglomerates, similar to other small alluvial fans along the Pyrenean mountain front (Williams et al., 1998) and the Catalan Coastal Ranges (Anadón et al., 1985, 1986). A midlatitude warm climate (tropical to sub-tropical) characterized the Late Eocene, with a change to a climate with a dry season during the latest Eocene, and drier climate conditions during the Early Oligocene (Solé \& de Porta, 1982; Cabrera \& Sáez, 1987; Sáez, 1987; Cavagnetto \& Anadón, 1996).

During the Palaeogene, sedimentation along the $\mathrm{N}$ and SE margins of the eastern Ebro Basin was coeval with thrust displacements and the generation of high relief. This is reflected in the development of progressive synsedimentary unconformities and growth folds in the alluvial fan conglomerates along both the Pyrenean margin (Berga Group: Riba, 1976; Anadón et al., 1986; Vergés et $\boldsymbol{a l . , 2 0 0 2 )}$ ) and the Catalan Coastal ranges (Anadón et al., 1985, 1986; López-Blanco et al., 2000; López-Blanco, 2002). Two Palaeogene fluvial fan systems of northern provenance (the Cardona-Súria and Solsona-Sanaiija fans) with radii of about 40 and $35 \mathrm{~km}$, and areas of 800 and
$600 \mathrm{~km}^{2}$, respectively, have been recognized in the eastern Ebro Basin (Fig. 1A). These have been identified on the basis of a radial arrangement of palaeocurrents (fig. 3, Malmsheimer et al., 1979; Sáez, 1987). The distal deposits of the CardonaSúria fluvial fan system are exposed in a N-S orientated, discontinuous cross-section, $10 \mathrm{~km}$ long, where the Cardener River trenches although the Cardona and Súria anticlines (Fig. 1B). The distal deposits of the Solsona-Sanaiija fluvial fan occur in a continuous W-E orientated, $5 \mathrm{~km}$ long exposure, which corresponds to the $\mathrm{N}$ flank of the Ponts-Calaf anticline (Fig. 1B). Although the fluvial-lacustrine successions in both areas were coeval, the western succession (Solsona-Sanaiija) shows thicker lacustrine deposits than that in the east (Cardona-Súria) because the eastern shoreline of the lake stepped westwards as fluvial fans expanded from $\mathrm{N}$ and $\mathrm{S}$ during the Palaeogene.

The locations of the fluvial fan outlets in the northern basin margin were controlled by the position of the main palaeovalleys which flowed transverse to the south-Pyrenean Thrust Front (Fig. 1). In particular, the Súria-Cardona fluvial fan was fed by the drainage which formed to the $\mathrm{E}$ of the Pedraforca thrust sheet, North of Berga (Fig. 1B). This setting constitutes the modern upper Llobregat River valley (Fig. 1A and B). The Solsona-Sanaïja fluvial fan was fed by the drainage basin which formed to the $\mathrm{E}$ of a lateral ramp associated with the Montsec thrust sheet. This drainage basin partially corresponds today to the upper Cardener River valley (Fig. 1A and B). Similar features have been described by Nichols \& Hirst (1998) and Jones (2004) in the southern central Pyrenees where the main rivers generating Oligo-Miocene fluvial fans were spaced at a regular distance of $20-30 \mathrm{~km}$.

The Upper Eocene-Lower Oligocene fluvial fan deposits along the Pyrenean margin of the basin (Berga Group, Solsona and Súria formations) pass laterally, in the centre of the basin, into lacustrine deposits of the Barbastro (evaporites), Torà (sandstones and siltstones) and Castelltallat (limestones) formations (Sáez, 1987; Anadón et al., 1992; Del Santo et al., 2000; Fig. 2). The overall stratigraphic pattern comprises a vertical superposition of coarse alluvial deposits on fine alluvial deposits, which in turn overlie evaporite and/or carbonate lacustrine deposits. This coarsening-upward megasequence was formed by the progradation of the fluvial fan systems from the north, linked to the N-S advance of the Pyrenean thrust front and to the growth of the hinterland catchment areas. The latter may have been 


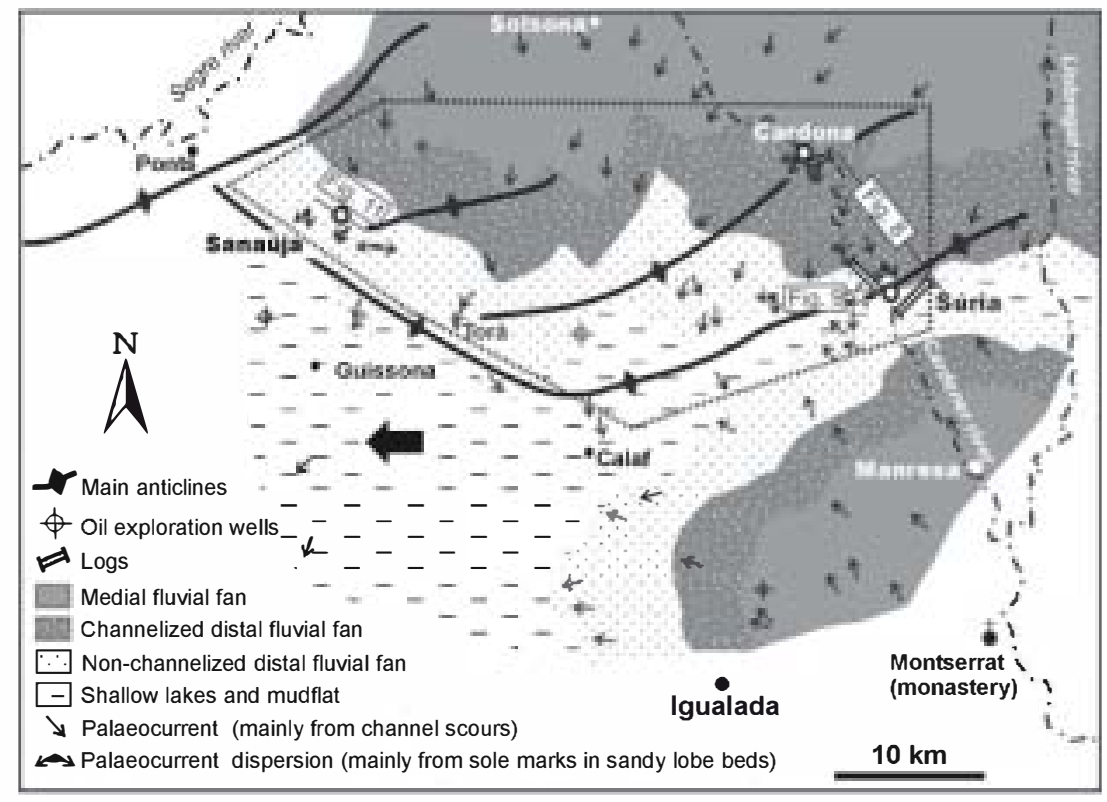

Fig. 3. Palaeocurrent summary and palaeoenvironmental map for the Upper Eocene-Lower Oligocene, eastern Ebro Basin. Two fluvial fan systems which were fed from the northern (Pyrenean) margin of the basin can be distinguished based on the palaeocurrent distribution: the Cardona-Súria and Solsona-Sanaüja fluvial fans. Palaeocurrents from the SE margin of the basin (Catalan Coastal Ranges) identify the Manresa-Igualada fluvial fan. The large arrow indicates the migration direction of the eastern margin of the lacustrine system during the Palaeogene. Modified from Malmsheimer et al. (1979) and Sáez (1987). sandy facies belts, 5-20 km wide, which are parallel to the Pyrenean front (Fig. 3). In the studied area, 14 sedimentary facies are distinguished (Table 1) on the basis of lithology, sedimentary structures, shape and width/thickness ratio of the sandy beds, trace fossils and colour. The vertical and lateral relationships between the facies have been used to establish seven facies associations (Table 2). These associations correspond to fluvial fan deposits, which comprise medial and distal fan deposits (the latter including channelized and non-channelized terminal lobe deposits), mudflat deposits and lacustrine deposits (including deltaic, evaporitic playa-lake and carbonate-rich nearshore-offshore deposits) and are described in more detail below.

\section{Fluvial fan facies associations}

The fluvial fan facies associations (Tables 1 and 2) that have been recognized in the studied area comprise medial and distal fluvial fan deposits. The distal fluvial fan association includes channelized (relatively proximal), and non-channelized (distal) terminal lobe deposits. The proximal fluvial fan facies are not exposed in the study area although, close to the Pyrenean front, they mainly consist of gravely to sandy stream flood deposits interbedded with alluvial-fan conglomerates transported by cohesionless gravity flows (Williams et al., 1998).

\section{Medial fluvial fan (MFF)}

This association consists mainly of very coarsegrained to fine-grained grey sandy channel-fill deposits (facies S1) which alternate with finegrained, red mudstone-dominated overbank deposits (facies M1) (Fig. 4). The channel-fill deposits display isolated ribbon geometries, are up to $3.5 \mathrm{~m}$ thick and $30-500 \mathrm{~m}$ wide, with a multistorey infill characterized by structureless and planar-cross or trough-cross bedded sandstones and mudstones (facies S1). Downfan, at the transition to the distal-fan deposits from the medial fluvial fan, the channel bodies show less incision and have a wider lateral extent (about $500 \mathrm{~m}$ ) than in more proximal settings. Low angle, sigmoidal cross stratification can be recognized as lateral accretion packages within the ribbon channel deposits (la in Fig. 4). The uppermost $10 \mathrm{~cm}$ of the sigmoidal sandbodies are very coarse-grained and show intense bioturbation. Trace fossils include structures similar to those ascribed to termite nests (e.g. Hasiotis, 2002, 2003), root traces and unfilled or passively filled vertical burrows that are locally Y-shaped (comparable with the beetle burrows of Hasiotis, 2003). Root traces and possible termite nest structures in the lateral accretion sandbodies indicate relatively long-term sub-aerial exposure of vegetated river benches (Buatois \& Mángano, 1995; Genise et al., 2000) in the medial fluvial fan area.

\section{Channelized terminal lobe}

This association consists of grey channel-fill sandstone beds up to $1.5 \mathrm{~m}$ thick and 50-100 m wide characterized by slightly erosive basal scoured surfaces (facies S2) which are amalgamated with sheet-like sandstone beds (facies S3), both forming 2-22 $\mathrm{m}$ thick, tabular sandy inter- 
Table 1. Facies description and interpretation.

\begin{tabular}{|c|c|c|c|}
\hline Facies & Lithelegy \& bed shape & Sedimentary structures \& fessils & Interpretation \\
\hline S1 (Fig. 4) & 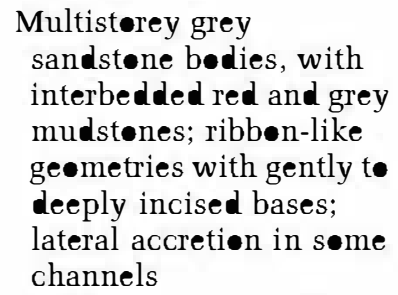 & 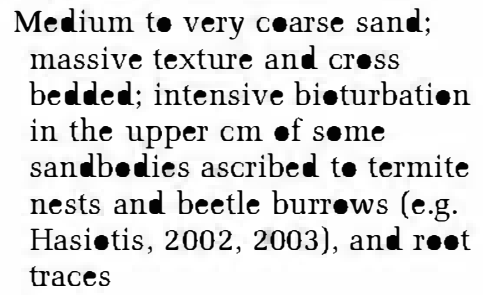 & 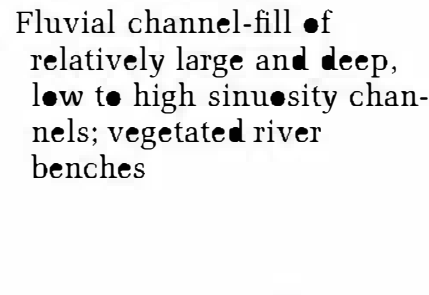 \\
\hline S2 (Figs 5 and 9) & $\begin{array}{l}\text { Multistørey channel-like } \\
\text { grey sandstøne, with } \\
\text { interbedded red mud- } \\
\text { stønes; slightly erøsive } \\
\text { bases }\end{array}$ & 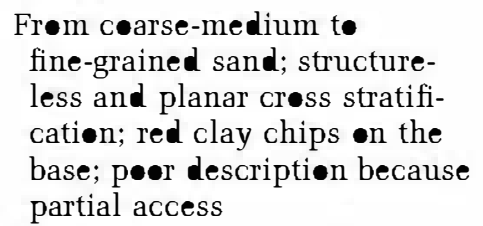 & $\begin{array}{l}\text { Fluvial channel-fill of løw } \\
\text { sinu } \bullet \text { sity, shalløw distribu- } \\
\text { tary channels }\end{array}$ \\
\hline S2a (Fig. 10) & 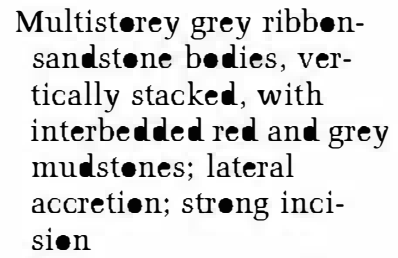 & 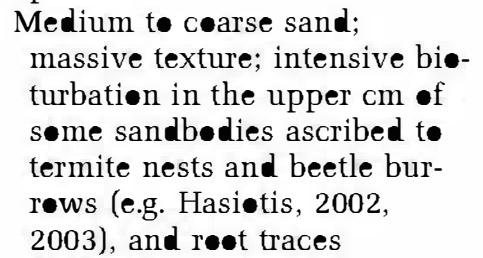 & $\begin{array}{l}\text { Fluvial channel-fill and } \\
\text { levees of deep, high sinu- } \\
\text { esity distributary channels; } \\
\text { high vertical accretien rate } \\
\text { (relatively preximal) }\end{array}$ \\
\hline S2b (Figs 8 and 9) & $\begin{array}{l}\text { Single, deep sceured } \\
\text { ribbøn sandstønes }\end{array}$ & $\begin{array}{l}\text { Medium to cearse sand; } \\
\text { massive texture; peør descrip- } \\
\text { tien because inaccessibility }\end{array}$ & 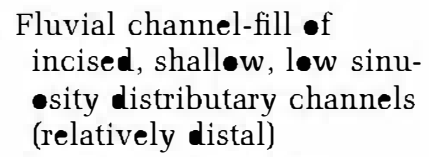 \\
\hline S3 (Figs 6 and 11) & $\begin{array}{l}\text { Grey and reddish single } \\
\text { tabular, sheet-like sand- } \\
\text { stene beds }\end{array}$ & 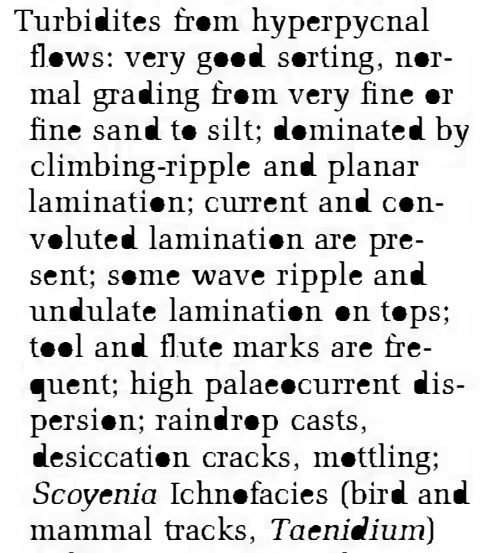 & 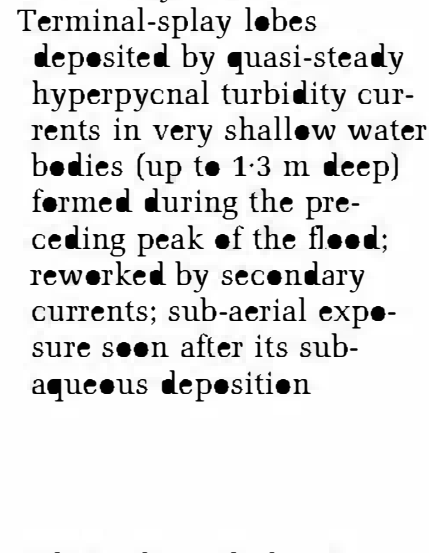 \\
\hline S4 (Figs 7A and 11) & 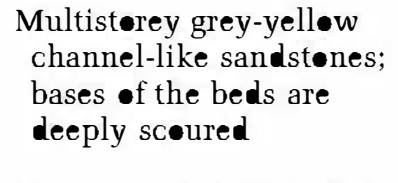 & 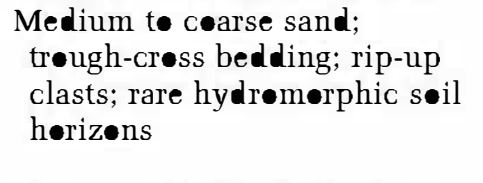 & 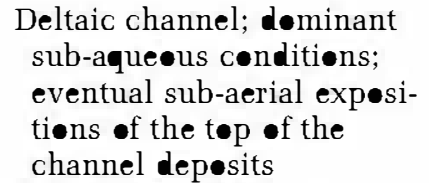 \\
\hline S5 (Figs 7A and 11) & $\begin{array}{l}\text { Single tabular, sheet-like } \\
\text { sandstene beds (less lat- } \\
\text { eral extensien than S3 } \\
\text { facies) }\end{array}$ & $\begin{array}{l}\text { Fine and grey sand; deminated } \\
\text { by climbing ripple and planar } \\
\text { laminatiøn; absence of trace } \\
\text { fessils }\end{array}$ & 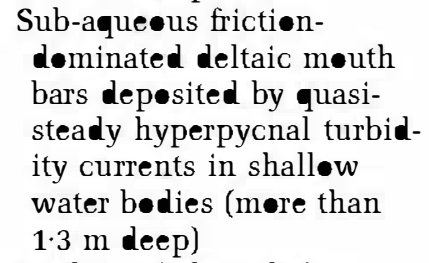 \\
\hline M1 (Fig. 9) & Red mudstenes & 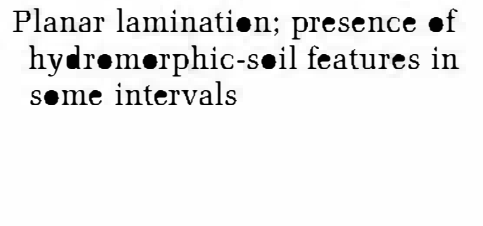 & 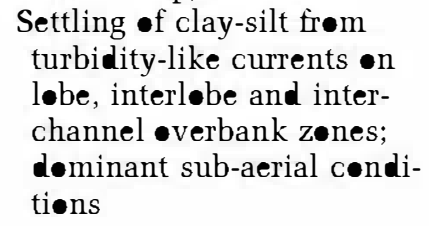 \\
\hline
\end{tabular}


Table 1. (Continued).

\begin{tabular}{|c|c|c|c|}
\hline Facies & Lithøløgy \& bed shape & Sedimentary structures \& fessils & Interpretatien \\
\hline M2 (Fig. 9) & Grey-blue mudstenes & $\begin{array}{l}\text { Planar laminatiøn; gypsum } \\
\text { n॰dules }\end{array}$ & 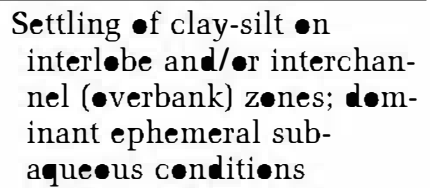 \\
\hline M3 (Fig. 7A) & $\begin{array}{l}\text { Yellew t• brøwn mud- } \\
\text { stønes }\end{array}$ & Massive texture & $\begin{array}{l}\text { Settling of clay-silt plumes } \\
\text { in predelta and interdis- } \\
\text { tributary bay zenes; peren- } \\
\text { nial lake, deeper than } 1.3 \mathrm{~m}\end{array}$ \\
\hline St (Fig. 7B and C) & $\begin{array}{l}\text { White siltstenes; variable } \\
\text { carbønate centent }\end{array}$ & $\begin{array}{l}\text { Strømatelites, gypsum crystal } \\
\text { casts, chert nedules and flaser } \\
\text { sandy laminatiøn }\end{array}$ & 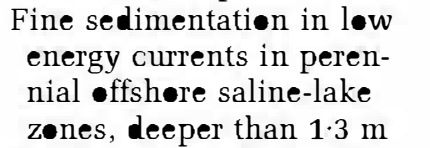 \\
\hline G & $\begin{array}{l}\text { White-grey gypsum in } \\
\text { tabular beds; very fine } \\
\text { grey clay laminae inter- } \\
\text { bedded }\end{array}$ & Nedular and laminated textures & 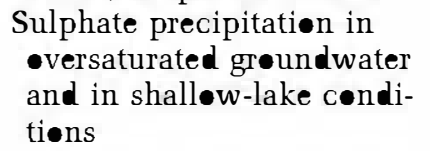 \\
\hline Ms & Grey-blue marlstenes & $\begin{array}{l}\text { Lecally centain char phyte } \\
\text { remains }\end{array}$ & $\begin{array}{l}\text { Ephemeral pends in terminal } \\
\text { løbe and interløbe areas }\end{array}$ \\
\hline $\mathrm{L}$ & $\begin{array}{l}\text { (A) Tabular light grey } \\
\text { limestønes; (B) lenticular } \\
\text { dark grey-black, silty- } \\
\text { sandy limestønes }\end{array}$ & 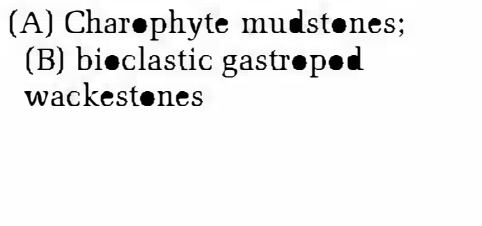 & $\begin{array}{l}\text { (A) Offshøre carbønate and } \\
\text { fine-siliciclastic sedimenta- } \\
\text { tiøn in freshwater-lake; (B) } \\
\text { nearshøre carbønate and } \\
\text { fine-siliciclastic sedimenta- } \\
\text { tiøn in freshwater-lake }\end{array}$ \\
\hline
\end{tabular}

Table 2. Facies asseciatiens and interpretatiøn.

Facies

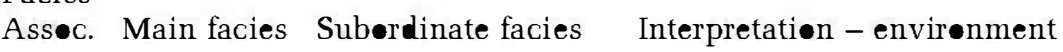

\begin{tabular}{|c|c|c|c|}
\hline MFF & S1, M1 & & Medial fluvial fan: fluvial channel and vegetated everbank \\
\hline CTL & S2, S3 & M1, S2a & Distal fluvial fan: channelized (preximal) terminal løbe \\
\hline NCTL & S3 & S2, M1, M2, M3, Ms & Distal fluvial fan: nøn-channelized (distal) nen-vegetated terminal løbe \\
\hline $\mathrm{MF}$ & M1, M2 & $\mathrm{S} 2 \mathrm{~b}, \mathrm{~S} 3$ & Mud-flat \\
\hline DL & $\mathrm{S} 4, \mathrm{~S} 5, \mathrm{M} 3$ & & $\begin{array}{l}\text { Fluvial-deminated delta (channels, møuth bars, predelta and } \\
\text { interdistributary bay) }\end{array}$ \\
\hline PL & G & M2, M3 & Very shallew, ephemeral saline playa-lake \\
\hline CL & St, L, Ms & S3, M2, M3 & Offshøre-nearshere carbenate, perennial freshwater er saline lake \\
\hline
\end{tabular}

vals which can be wider than $10 \mathrm{~km}$ laterally (Fig. 5). The sandstone intervals alternate with 2$28 \mathrm{~m}$ thick, red (facies M1) and grey (facies M2) mudstone-dominated beds. The above facies are arranged in 6-45 $\mathrm{m}$ thick coarsening-upward and fining-upward sequences. The slightly channelized beds (facies S2) which characterize this facies association consist of up to $1.5 \mathrm{~m}$ thick coarse to fine sandstones that are either structureless or show trough cross bedding.

The shape, sedimentary structures and the association with sheet-like sandy facies indicate that facies S2 corresponds to channel-fill deposits. The channels developed as distributary networks in the proximal portions of terminal lobes.

\section{Non-channelized terminal lobe}

This facies association is dominated by thin grey and locally reddish tabular sandstone beds, 10$20 \mathrm{~cm}$ thick, with a lateral extent of between 100 and $600 \mathrm{~m}$, which were originally deposited by expanded floods (facies S3, Fig. 6A and B). The sandstone beds may be amalgamated or they can alternate with finely laminated red to grey-blue mudstone and, occasionally, grey marlstone (facies M1, M2 and Ms). Overall, the beds are arranged in coarsening-upward or fining- 


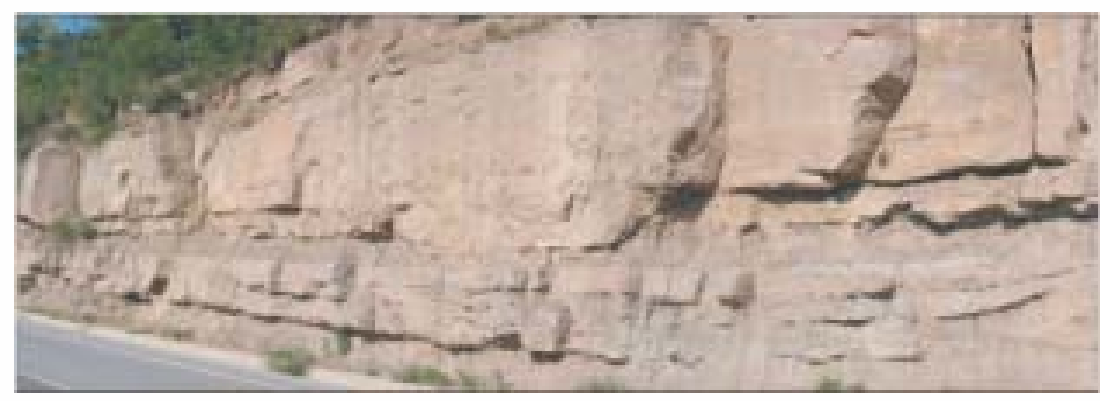

Fig. 4. Sand-dominated low-sinuosity fluvial deposits of the medial fluvial fan association (MFF), Solsona Fm. between Súria and Cardona villages: $c h$, channel fill; la, lateral accretion.

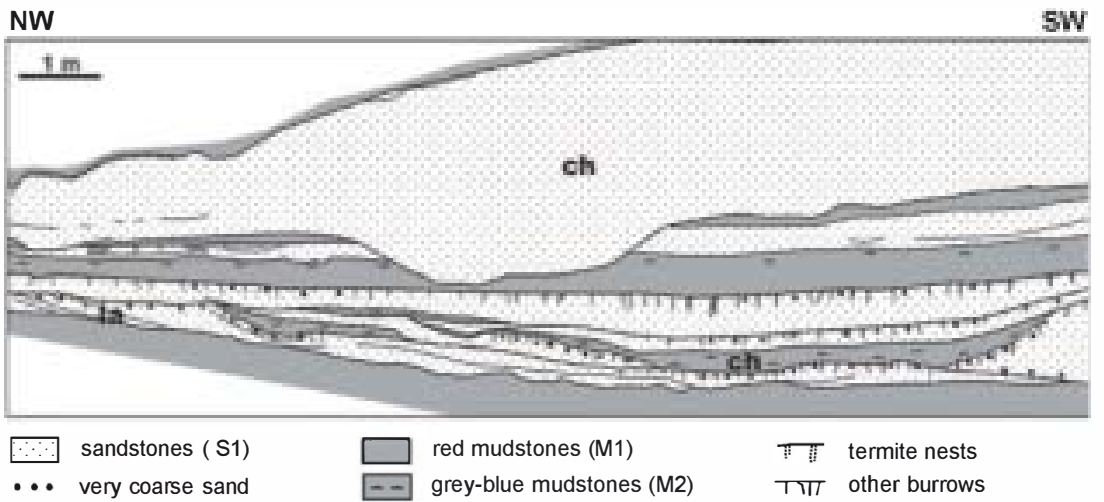

Fig. 5. (A) Detail of sand-dominated, channelized terminal lobe deposits (CTL f.a.) at Súria. (B) Interpretative facies panel. Dashed lines indicate thin mudstone beds which separate the coarseningfining-upward minor cycles (metrescale in thickness). Cycle limits and sequential trends are indicated by symbols to the right of the panel. See person for scale.
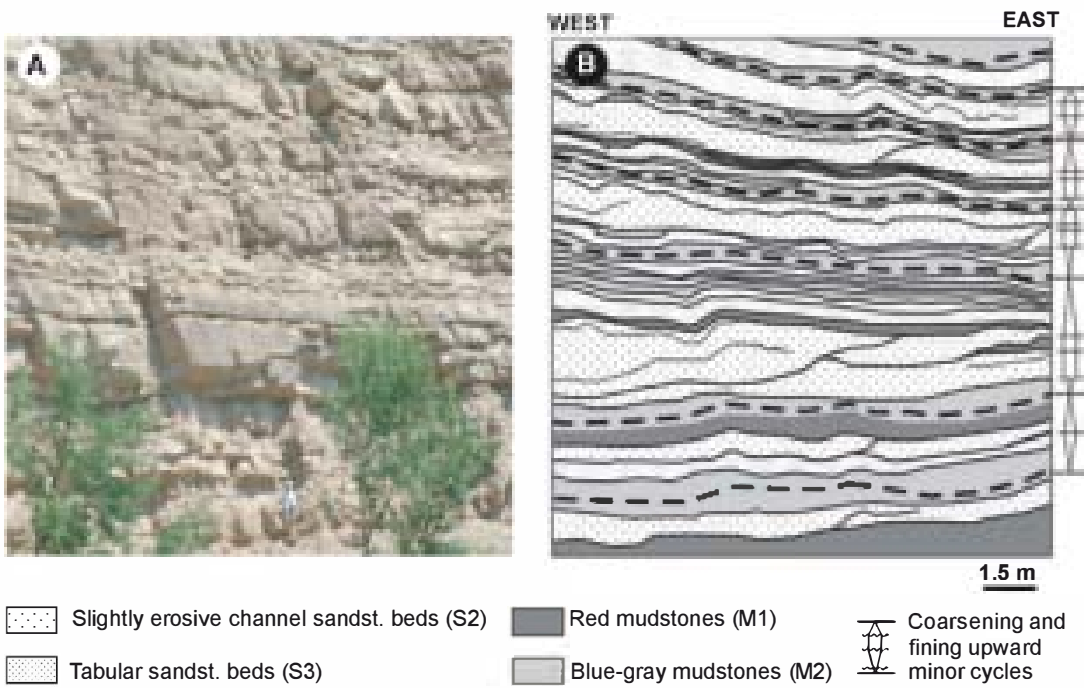

upward sequences. Poorly developed hydromorphic palaeosols which can be traced for over $500 \mathrm{~m}$ appear between red mudstones.

The tabular sandstone beds (facies S3, Table 1) show very good sorting, normal grading from very-fine or fine sand to very-fine-sand or silt dominated by climbing-ripple (Fig. 6D) and planar lamination. There are also structureless layers and layers displaying symmetric current-ripple and convoluted lamination, and tool and flute marks (Fig. 6E) are present on some bed bases. The assemblage of features indicates that the sandstone layers were deposited mainly by quasisteady hyperpycnal turbidity currents, formed when sediment-laden fluvial flood discharges entered standing, lower-density water bodies (Mulder \& Alexander, 2001; Zavala et al., 2006). Temporary shallow lakes may have formed during peak flood conditions. Some sandstone beds have wave rippled (Fig. 6D) and undulating top surfaces, together with climbing ripple lamination (Fig. 6C). These features suggest secondary currents reworked the top surface of the fine sand deposits. Rain drops (Fig. 6F), desiccation cracks, trace fossils characteristic of the Scoyenia ichnofacies (i.e. bird tracks, Fig. $6 \mathrm{H}$, and Taenidium, Fig. 6J) and mammal tracks (Fig. 6G) often characterize the tops of the sandstone beds in medial 


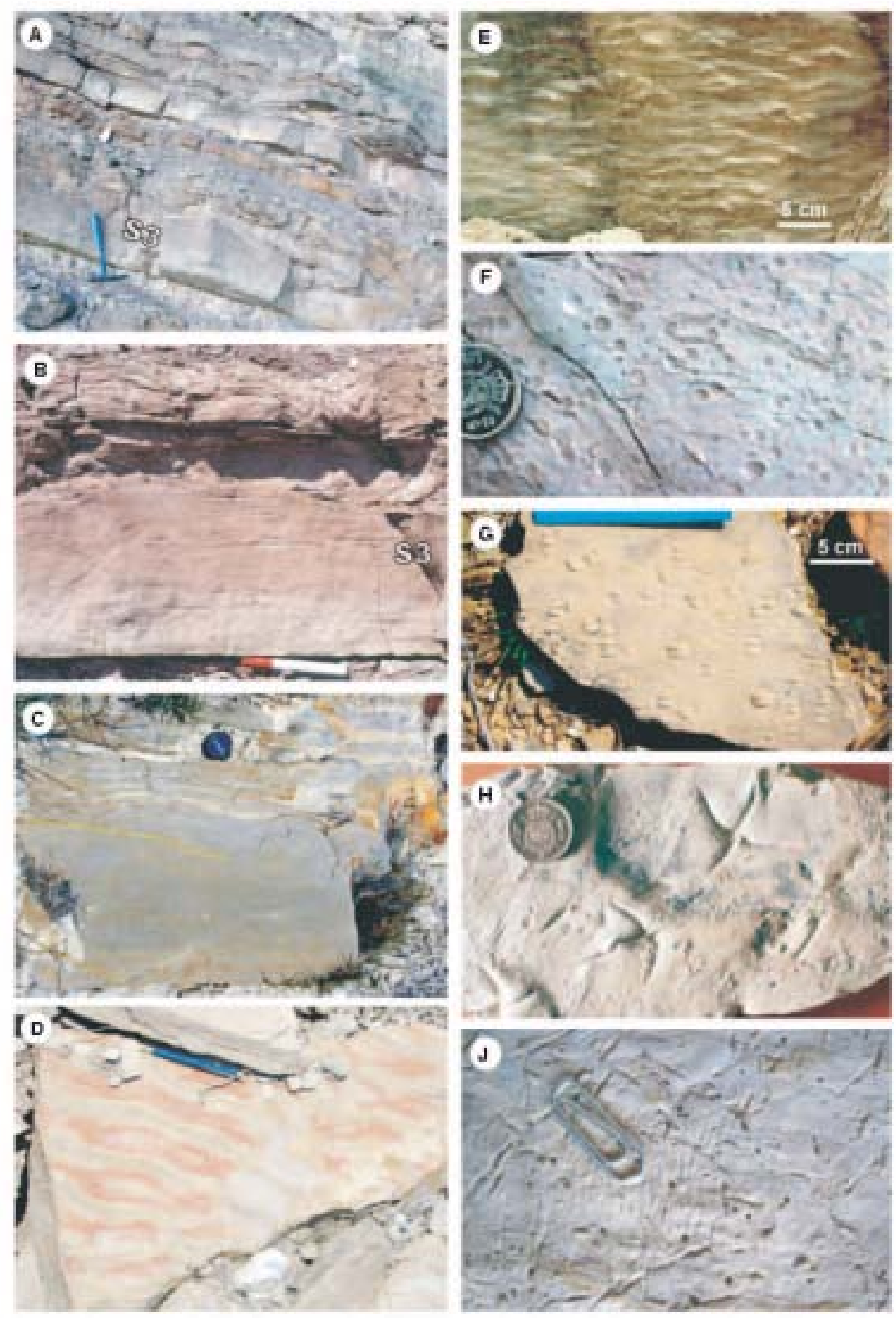

Fig. 6. Nen-channelized terminal lebe depesits (NCTL) at Cardena. (A) Tabular sheet-like sandstene beds (S3) alternating with red and grey-blue mudstenes (M1 and M2). (B) Detail of tabular, sheet-like, fine-grained sandstene bed (labelled S3 in A) shewing nermal grading, geed serting and climbing ripple laminatien fermed by hyperpycnal turbidity current precesses. Nete the drab lewer part and the reddish upper part of the sandstene bed. The upper sandy bed shews defermatien structures which cerrespend te mammal tracks. (C) Tabular sandstene bed, shewing undulated tep surface, asseciated with climbing ripple laminatien. (D) Wave ripples at the top ef a sheet-like sandstene bed. (E) Flute and to els marks at the base of a sheet-like sandstene bed. (F) Rain dreps marks at the tep of a sheet-like sandstene bed. (G) Mammal tracks at the top of a sheet-like sandstene bed. (H) Bird tracks (Scojenin ichnefacies) at the tep of a sheet-like sandstene bed. (J) Thenidium trace fessil (Scoyenim ichnefacies) at the tep of a sheet like sandstene bed. 
and upper parts of the coarsening-upwards sequences, all indicating sub-aerial exposure soon after deposition. These structures also indicate that wet and soft grounds were formed during periods of rapid fluctuation of a relatively high water table (Buatois \& Mángano, 1998) with scarce or absent vegetation. The existence of these persistent wet grounds is in contrast to the medial fluvial fan where interchannel areas were predominantly dry.

The wide palaeocurrent dispersion (Fig. 3) and the association with channelized facies indicate that the tabular sheet-like sandstones correspond to lobe deposits which spread out as frontal (and possibly lateral) splays generated at the distal termination of distributary fan channels. Terminal lobes were formed by density underflows into very shallow ephemeral standing bodies of water that onlapped the fan toes during and immediately following flood events in distal fluvial fan areas. The dominance of climbing ripple structures indicates that lobe deposits are related to sub-aqueous traction-plus-fallout processes generated by turbulent flows with a high suspended load (Jopling \& Walker, 1968; Mulder \& Alexander, 2001; Mulder et al., 2003). The abundance of sub-aerial organic and inorganic structures on the top of the sandstone beds indicates a short duration for the standing shallow water body, which probably dried out by evaporation and/or water infiltration into the previously deposited sandy lobe deposits. However, the sandstones interbedded with grey-blue mudstones or marlstones in the lower parts of the coarsening-upwards sequences and those sandstone beds which are overlain by carbonates indicate persistent standing bodies of water following sand-sheet deposition.

\section{Mudflat (MF)}

This association consists of finely laminated red (facies M1) or grey-blue (facies M2) mudstones. These facies form several metres thick intervals associated with the lower part of coarseningfining cycles of the terminal lobe facies (NCTL and CTL facies associations). The relative abundance of red and grey-blue mudstones depends on the context. Red mudstones are more abundant close to the transition to the terminal lobe sandy deposits and usually contain thin sandy-silty beds with ripple lamination. Grey-blue mudstones are more abundant at the lateral and vertical transitions to the evaporite playa-lake facies (facies PL) and may contain lenticular gypsum beds and locally sparse gypsum nodules.
The red mudstones are interpreted as proximal mudflat deposits fringing the terminal lobes. Locally, primary lamination is obscured by the occurrence of gypsum nodules. The grey-blue mudstones are interpreted as distal mudflat deposits, appearing as a continuous fringe passing laterally into lake facies.

\section{Lacustrine facies associations}

Deltas (DL)

This association consists of grey-yellow ribbon sandstones (high width/height ratio in transverse section) to sheet-like channelized sandstones up to $1.6 \mathrm{~m}$ thick and $\mathbf{1 0 0}-\mathbf{5 0 0} \mathrm{m}$ wide (facies $\mathrm{S} 4$ ), grey-yellow, sheet-like, tabular fine sandstones from 10 to $40 \mathrm{~cm}$ thick and 50-300 m wide (facies S5) and yellow to brown mudstones (facies M3). These facies are arranged in 1.3-3.5 m thick coarsening-upward sequences (Fig. $7 \mathrm{~A}$ ). No signs of sub-aerial exposure have been found in this association. Usually, the channel-fill deposits (facies S4) are composed of coarse to medium sandstone and are vertically amalgamated forming sandstone packages up to $2.5 \mathrm{~m}$ thick. They exhibit trough cross-bedding, flat lamination, ripup clasts at the base and hydromorphic soil horizons on top. The sheet-like sandstones are dominated by climbing ripple and planar lamination or structureless layers (facies S5, Table 1). Deltaic mouth bars have more restricted lateral extents than the terminal lobes.

These deposits are interpreted as fluvialdominated prograding deltas, in which finegrained prodelta and interdistributary bay (facies M3), mouth bar (facies S5) and channel fill (facies S4) deposits may be differentiated (Fig. 7A). This is mainly based on the sequential coarseningupward arrangement and their stratigraphic position between red distal fan and lacustrine offshore deposits. A lower density for the lake water compared with the fan channel effluent and shallow lake conditions favoured the formation of high width/height ratio friction-dominated mouth bars. Other deposits described in shallow lacustrine ancient record (Farquharson, 1982; Cabrera, 1983) are similar in bed lateral extent and sequential thickness. As for the terminal lobes, sub-aqueous traction-plus-fallout processes generated by turbulent flow with high suspended load dominated mouth bar deposition. Lacustrine delta facies recognized in the Sanaiija outcrop are interpreted as permanently sub-aqueous deposits except for hydromorphic soils developed in the capping channel facies reflecting overall progra- 


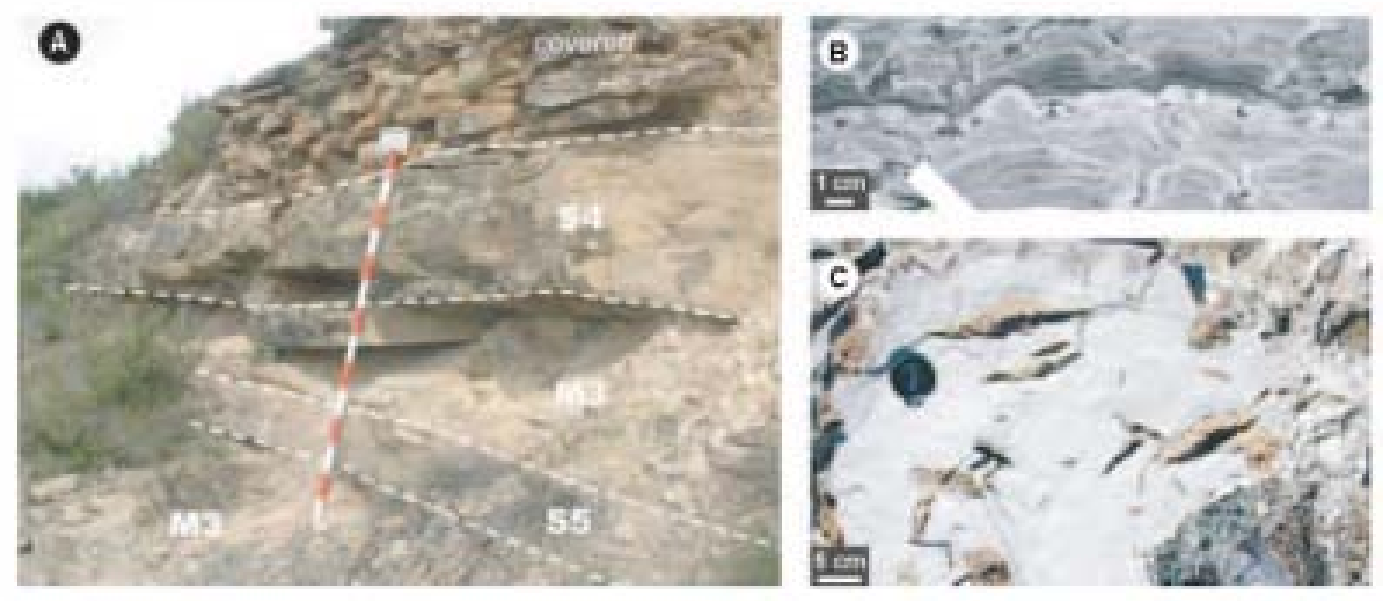

Fig. 7. (A) Offshere lacustrine depesits (facies M3), meuth-bar (facies S5) and channel (facies S4) ferming a cearsening-upward sequence because of lacustrine delta pregradatien (Sub-unit F, Fig. 1 in Sanaüja secter. (B) Lacustrine effshere depesits in Upper Terà Fm. shewing strematelitic laminatien in carbenate siltstenes (facies St). (C) Detail ef lacustrine effshere depesits in Upper Terà Fm. shewing lenticular gypsum casts in massive carbenate siltstenes (facies $\mathrm{St}$ ).

dation. Although well developed red sub-aerial delta top facies are not recorded in the outcrop, it is possible that they are present in more proximal locations.

\section{Eveporitic pleye-lake (PL)}

This association consists of gypsum beds (facies G) in $3-2 \mathrm{~m}$ thick intervals that alternate with grey-blue and yellow mudstones (facies $\mathrm{M} 2$ and M3). Gypsum beds are tabular, $10-30 \mathrm{~cm}$ in thickness, and mainly display nodular facies associated with fine-grained or microcrystalline laminated layers. The laminated gypsum intervals, u to $0.5 \mathrm{~m}$ thick, consist of alternating laminae of white or grey gypsum and grey clay. Nodular and laminated intervals can reach more than $10 \mathrm{~km}$ in extent.

The nodular gypsum formed interstitially in the clayey sediments as anhydrite nodules by evaporitic puming (Hsii \& Siegenthaler, 1969) in marginal sub-aerial zones of the lake, whereas the laminated gypsum formed in saline sub-aqueous environments which experienced evaporative concentration alternating with clay deposition during major floods. The repeated alternation of nodular and laminated gypum facies forming intervals up to $1 \mathrm{~m}$ thick and several kilometres in lateral extent indicate high-frequency oscillation of lake level (Hardie et al, 1978; Salvany, 1997; Arenas \& Pardo, 1999).

\section{Carbonete-rich lake and ponds (CL)}

Facies St consists of m-thick, white siltstone intervals with a variable carbonate content. The siltstone may be finely laminated, massive or display lenticular (flaser) bedding of fine sand. Some carbonate-rich intervals show irregular and wavy lamination that may be stromatolitic (Fig. 7B). Occasionally, the siltstones contain gypsum casts (Fig. 7C) and chert nodules. These facies originated in an offshore shallow lacustrine environment with an oscillating water level, and consequent saline and diluted phases.

Facies $\mathrm{L}$ are limestone beds, $5-30 \mathrm{~cm}$ thick, that commonly alternate with grey mudstones (facies M2), forming limestone-rich intervals several metres thick. Two limestone lithofacies, forming several $\mathrm{dm}$-thick to $\mathrm{m}$-thick shallowing-up cycles have been recognized: (i) light-grey massive carbonate mudstone with abundant charophyte gyrogonites; and (ii) lenticular beds of dark, organicmatter rich, sandy wackestone with mollusc-shell fragments and root traces. These lithofacies are intermeted as freshwater carbonates that accumulated in offshore and nearshore shallow lacustrine environments respectively (Sáez, 1987; Cabrera \& Sáez, 1987).

Facies Ms are grey-blue marlstone intervals that locally contain charowyte remains and are usually intercalated with tabular sandstones representing terminal lobe deposits (facies S3). They are interpreted as resulting from ephemeral ponding in terminal interlobe areas.

\section{TERMINAL LOBE EVOLUTION - IISTAL CAR DONA-SÚRIA FLUVIAL FAN}

Correlation between the Cardona and Suria successions in a NNW-SSE, proximal-distal section 


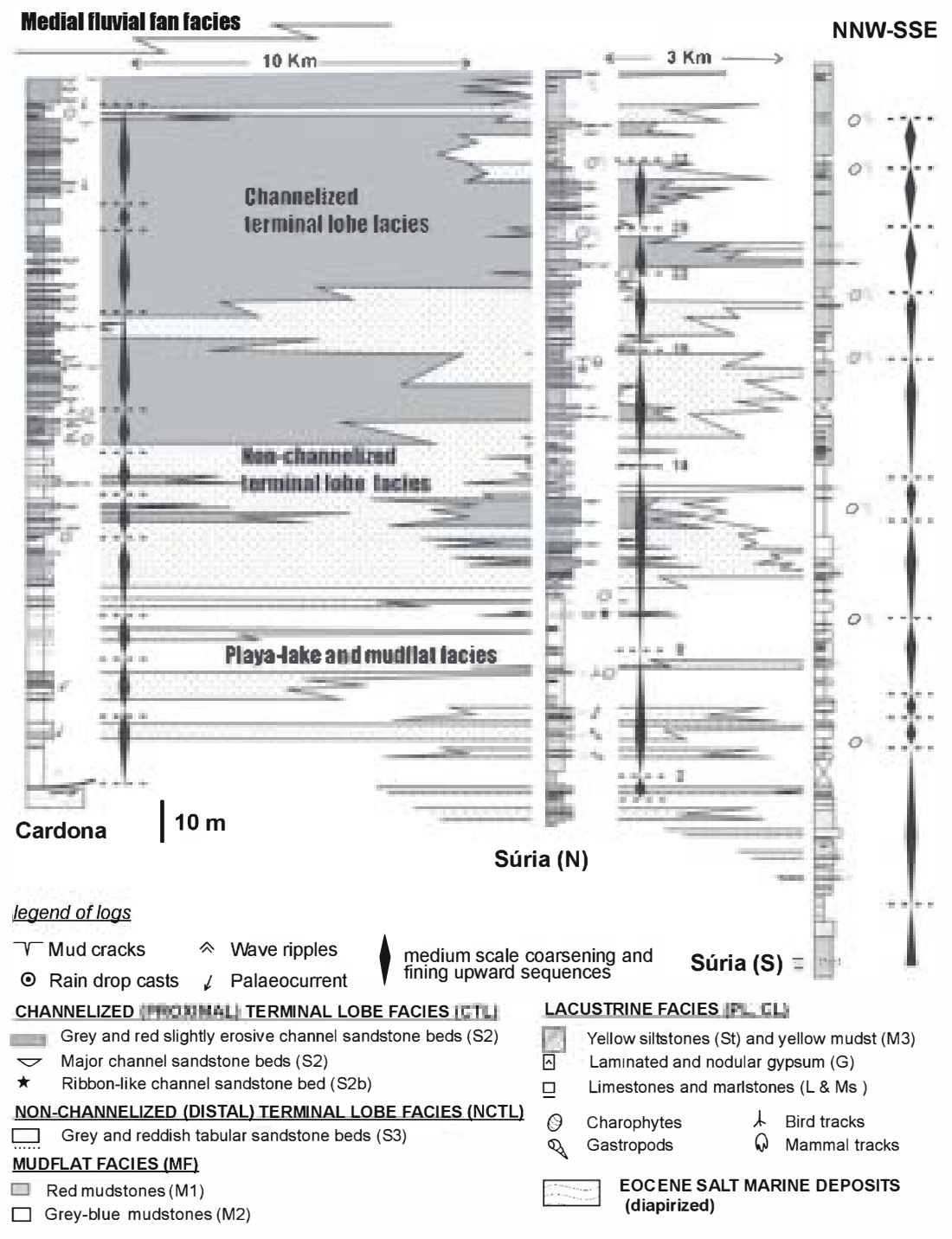

Fig. 8. Cardona-North Súria-South Súria correlation panel showing the lateral and vertical relationships between terminal lobe, mudflat and lacustrine facies (Súria Fm.) over $13 \mathrm{~km}$. Correlation between the logged sections is mainly based on the thickest mudstone intervals and is tentative because of the lack of outcrop continuity. Note the progradation and retrogradation pulses of the terminal lobes recorded as mediumscale coarsening- and fining-upward sequences respectively. Only the thickest mudstone beds can be traced at kilometre scale (up to $13 \mathrm{~km}$ ). The stratigraphic position of the section is shown in Fig. 2. Cycle top numbers shown for North Súria correspond to those in the cross section of Fig. 9. along the Cardona-Súria fluvial fan system (Figs 2, 3 and 8) can be achieved by using the thicker mudstone intervals as key beds. A lateral transition over $13 \mathrm{~km}$ long between medial fluvial fan deposits (Solsona Fm.), distal fan (Súria Fm.), and mudflat facies (Súria Fm.) is evident. The correlation reveals an overall coarsening-upward megasequence, up to $800 \mathrm{~m}$ thick, which reflects the long term, $\mathrm{N}$ to $\mathrm{S}$ progradation of the Pyrenean alluvial system.

The lower $190 \mathrm{~m}$ of the Súria Fm. (Fig. 8) shows both lateral and vertical transitions from channelized terminal lobe facies (CTL), to nonchannelized terminal lobe facies (NCTL), to mudflat deposits (MF) and, locally, to carbonate lacustrine facies (CL). Lacustrine, mudflat and sandy terminal lobe facies are also arranged in medium scale, tens-of-metres-thick coarseningupwards sequences, as a result of progradation pulses of the alluvial system (Fig. 9). Most of these sequences are overlain by poorly defined fining-up sequences that represent the retrogradational part of a progradation-retrogradation stack of distal fan environments. The retrogradational deposits culminate with the expansion of mudflats or the transgression of very shallow ephemeral water bodies onto sandy terminal lobe deposits (Fig. 9). One complete progradationretrogradation cycle may range in thickness from several metres to about $40 \mathrm{~m}$. The largest outcrops in Súria show a lateral change from channelized facies to non-channelized facies. This change is observed in Fig. 9, from west to east, between key beds 14 and 22. The correlation between the Cardona and Súria exposures (Fig. 8) suggests that the length of individual terminal lobe bodies may exceed $10 \mathrm{~km}$.

The sandstone-dominated parts of the progradation-retrogradation terminal lobe sequences also include minor coarsening-upward to fining- 

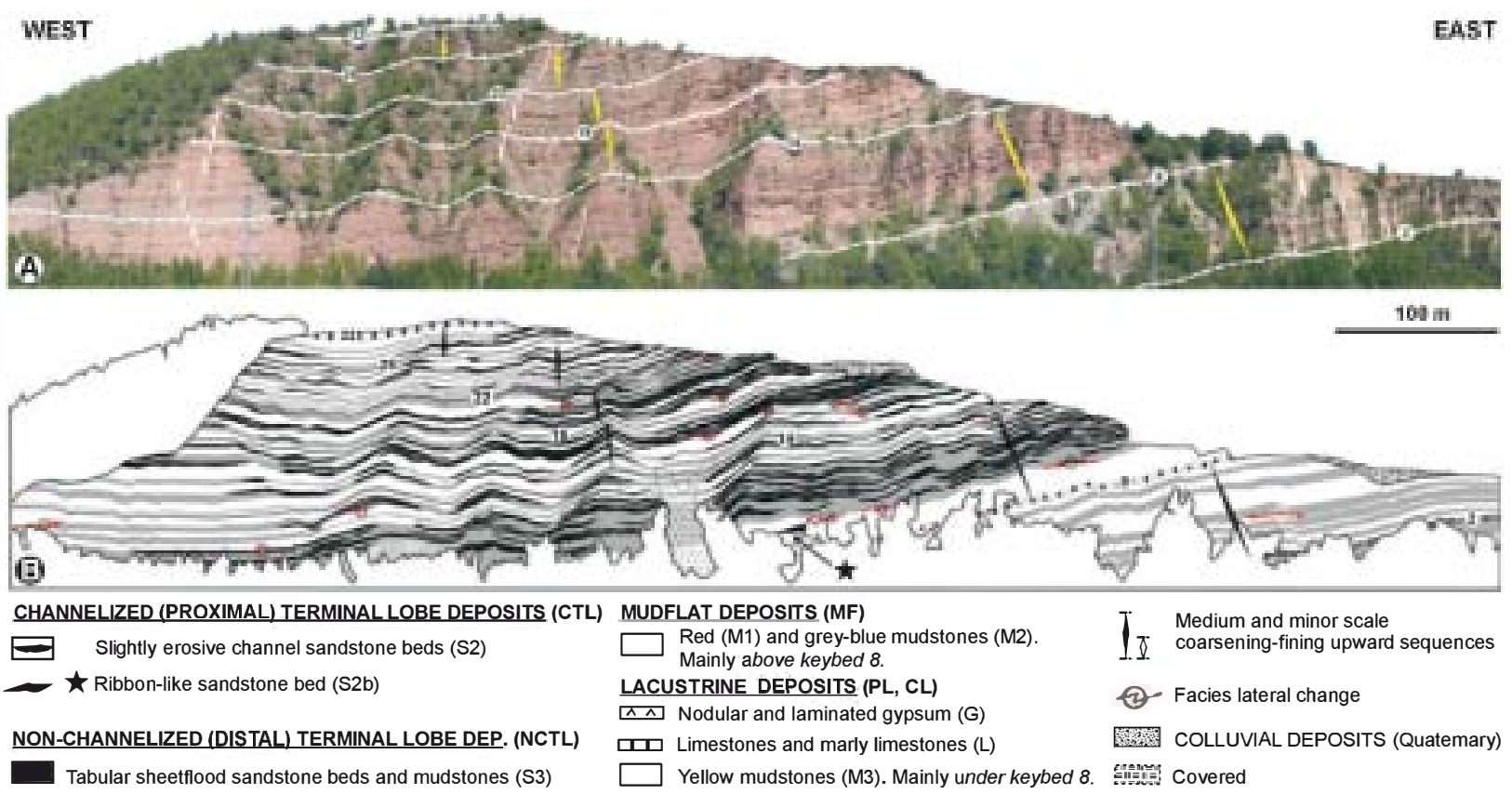

Fig. 9. (A) Terminal lobe, mudflat and lacustrine deposits of the Lower Súria Fm. (1 km to the West of Súria village). Boundaries of major and minor coarsening-fining-upward cycles are indicated. Major cycles correspond to progradation-retrogradation sequences of terminal lobes and are tens of metres thick (key bed numbers correspond to those of Fig. 8). Minor cycles are metre-scale in thickness and are mainly controlled by the topographic compensation between single lobes and channel sandstone beds. (B) Interpretative facies cross section. Note that between key beds labelled 8 and 22, the relative proximal channelized facies located to the east passes gradually to distal-marginal nonchannelized sandstone and mudflat facies. The density of channels diminishes also to the west.

upward cycles. These minor cycles, which are better recognized in the CTL facies (Fig. 5), are 1$3 \mathrm{~m}$ in thickness and comprise 5-10 sandstone beds. In the channelized terminal lobe facies, the sheet-sandstone and channel-sandstone beds show lateral pinch-outs. These cycles probably reflect lobe switching because of compensation of successive flood deposits (Fig. 5).

Isolated lenses comprising deeply incised channel-fill deposits occur within the mudflat or the distal-fan deposits of the thickeningupward sequences. These channel deposits are ribbon-like and exhibit both low width/height ratio and high vertical-accretion rates. Channels in the terminal lobe deposits are dominated by facies S2a, and a typical example is shown in Fig. 10. The channel fill here is $2.5 \mathrm{~m}$ thick, with sandy and muddy lateral accretion sigmoidal bodies (la in Fig. 10) and levee deposits ( $p l$ and $d l$ in Fig. 10). The coeval levee deposits are up to $0.5 \mathrm{~m}$-thick and extend from the opposite margin of the channel to that with lateral accretion deposits. Proximal levee deposits (pl in Fig. 10) form wedge-shaped sandstone deposits with dense root traces and internal fractures, and are contiguous with the channel fill deposits, whereas distal levee deposits ( $d l$ in
Fig. 10) are represented by tabular sandstone with intense bioturbation by beetles. The relationship of these channels to flood plain deposits is not observed. The exceptional preservation of levee deposits may have been favoured by strongly aggrading conditions and rapid channel avulsion (Brierley et al., 1997). Channel deposits in the mudflat facies (facies S2b) are anomalously deeply incised (up to $1.5 \mathrm{~m}$ ) and are interpreted to reflect base-level falls. These lake-level falls occurred during rapid and prolonged phases where the shoreline of the low gradient playa-lake system shifted to the south, resulting in incision of the distributary channels into the distal fan surface (facies S2a) and mudflat deposits (facies S2b). This interpretation is supported by the correlation of facies $\mathrm{S} 2 \mathrm{~b}$ channel deposits at the same stratigraphic level between two outcrops separated $1 \mathrm{~km}$ apart in the Súria area (see beds identified by asterisk above key bed 8 in Figs 8 and 9).

Deltaic sequences have not been recognized in the Cardona-Súria system. Periods of lake expansion generated fining-upward cycles which culminated in thin carbonate-lacustrine, palustrine and/or mudstone-dominated wet mudflat deposits (Fig. 8). 


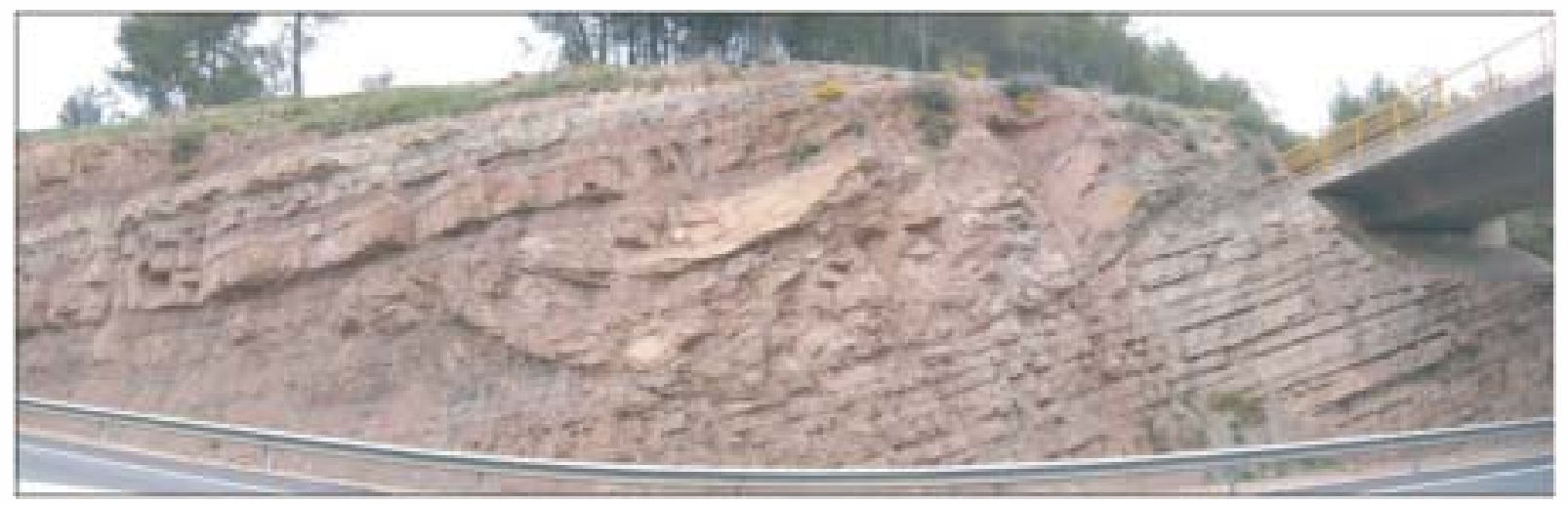

NW

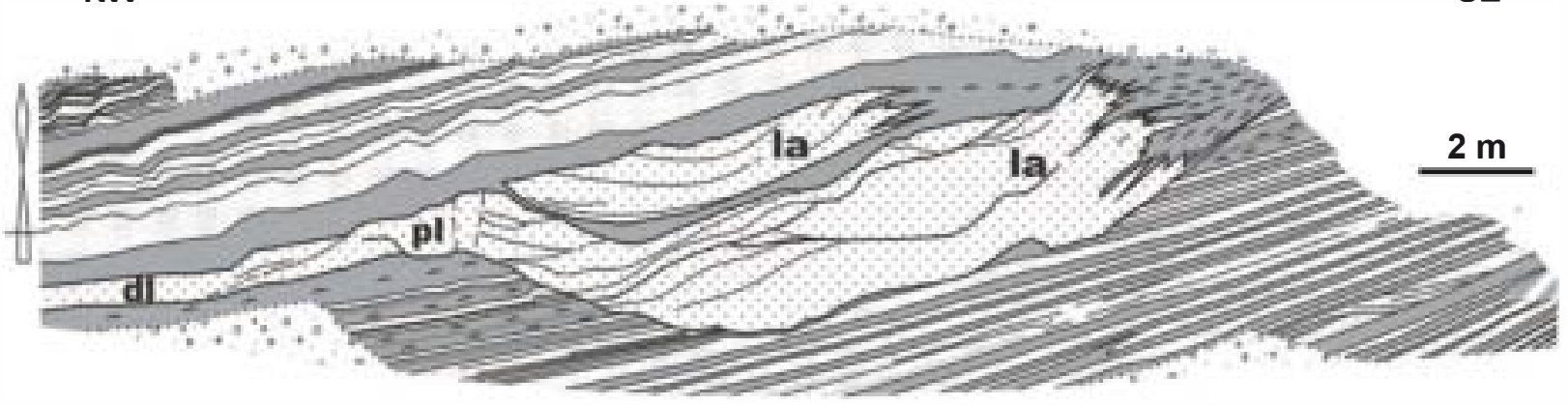

sandstones (facies S2a)

+ blue-gray mudstones (facies M2)

gray silty limestones (facies $L$ )

a... covered

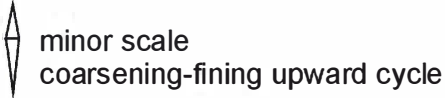

red mudstones (facies M1)

Fig. 10. Distributary ribbon channel fill (facies S2a) deeply incised into sheet-like terminal splay-lobe deposits (facies S3). Upper Súria Fm. between Súria and Cardona villages. Note the vertical accretion features of the channel fill bodies. la: lateral accretion, pl: proximal levee, $d l$ : distal levee.

\section{TERMINAL LOBE AND DELTA PROGR ADATION - DISTAL SOLSONA- SANAÜJA FLUVIAL FAN}

The stratigraphical correlation between the successions in the Cardona-Súria and SolsonaSanaüja areas (Fig. 2), including lithological data from the Guisona oil exploration well (Lanaja, 1987), shows that the coarsening-upwards megasequence of the Cardona-Súria fan system is the lateral equivalent of the same coarseningupwards megasequence in the Solsona-Sanaiija fan. However, whilst the distal exposures of the Cardona-Súria fan are dominated by terminal lobe deposits only, the Solsona-Sanaüja fan sequence contains evidence for episodic lake expansions and significant intervals of lacustrine facies (Fig. 11).

The Solsona-Sanaïja coarsening-upward megasequence is characterized by the superposition of three main sequences (Fig. 11B): (i) a lower sequence, up to $500 \mathrm{~m}$ thick, mainly com- posed of gypsum deposits which originated in an evaporitic playa-lake (Barbastro Fm.); (ii) a central sequence, $240 \mathrm{~m}$ thick, consisting of three intervals characterized by fluvial, deltaic and lacustrine sandstones and mudstones $(10,130$ and $25 \mathrm{~m}$ thick respectively), intercalated between evaporitic and carbonate lacustrine deposits (Súria and Torà Fms); and (iii) an upper sequence, several metres thick, composed of medial fluvial fan deposits (Solsona Fm.).

The upper interval of the central sequence includes five minor units $(1-5$, from base to top), and is particularly well exposed along a $5 \mathrm{~km}$ long, NE-SW cross section transverse to the transport direction of the Solsona-Sanaüja fluvial fan system (Fig. 11). A correlation panel (Fig. 11A) was made by laterally tracing individual sandstone beds between vertical measured sections. The facies composition and lithological transitions across these five units serves to illustrate the relationship between alluvial and lacustrine deposits in this area: 


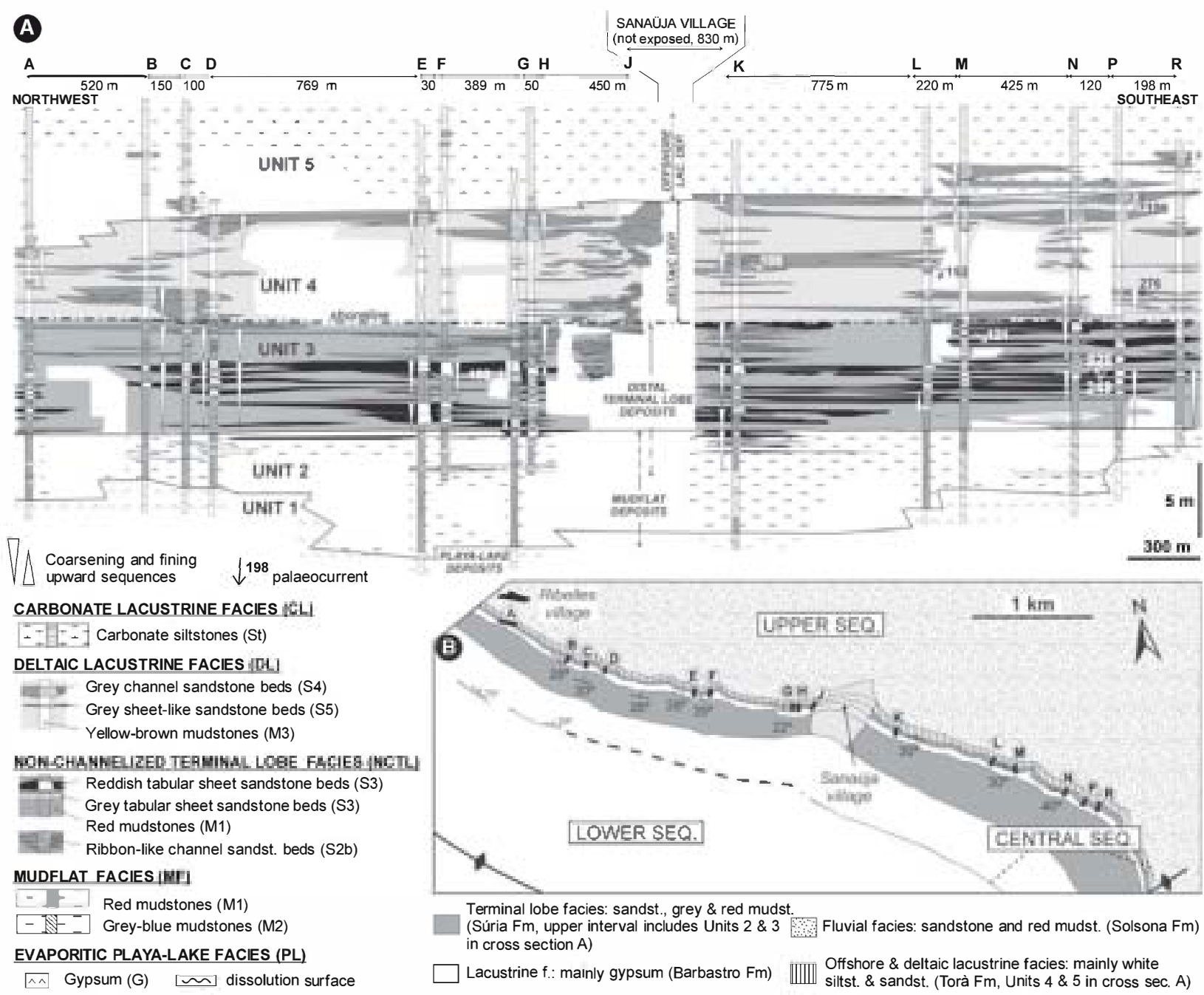

Fig. 11. (A) Cross section of distal Solsona-Sanaïja fluvial fan deposits in the western sector of the studied area. The stratigraphic location of the section is shown in Fig. 2. Minor coarsening- and fining-upward sequences of terminal lobe deposits and coarsening-upward sequences in deltaic deposits are displayed. (B) Geological map showing the main lithological units and location of logs shown in cross section A.

Unit 1 consists of $15 \mathrm{~m}$ of nodular and laminated gypsum (facies G) deposited in a shallow, playa-lake environment.

Unit 2 is mainly composed of red (facies M1) and grey-blue mudstones with gypsum nodules (facies M2). The upper part of this unit also shows intercalations of fine sandstones interpreted as turbidites and red mudstones (facies S3, M1). The transition from Unit 1 to Unit 2 occurs in two ways: (i) gradually, through the presence of increasingly lenticular gypsum beds (i.e. section C, in Fig. 11A); or (ii) sharply, marked by a gypsum dissolution surface (i.e. sections $B$ and $G$, in Fig. 11A). These features indicate a mudflat environment with ephemeral, saline ponding that eventually became diluted by freshwater floods from advancing fluvial fan channels.
Unit 3 consists of an alternation of grey and red tabular sheet-like sandstones (facies S3) and red mudstones (facies M1). Tabular sandy bed packages are arranged mainly in minor $1-3 \mathrm{~m}$ thick, coarsening-up sequences with channelized beds at the top which show less incision than those assigned to facies S2. Palaeocurrent trends from tool and flute marks show a large dispersion, indicating flow to the SE round to the W (Fig. 11A). Some minor fining-upward sequences occur laterally to the coarsening-up sequences, suggesting compensation (Fig. 11A).

The sandy lobes were generated as a consequence of flow expansion on terminal lobes. The flow expansion and the presence of hydromorphic palaeosols were favoured by gentle 
slopes (probably less than $\mathbf{0 \cdot 1 ^ { \bullet }}$, as described for Markanda terminal fan, Mukerji, 1976). During floods, water exiting terminal lobe channels spread out as frontal splays, explaining the wide palaeocurrent dispersal. Although the transverse orientation of the outcrops do not provide full details of the facies relationships, some terminal lobes were probably formed from lateral splays of the channels (crevasse splays) by analogy with the recent Neales Terminal splay (Lang et al., 2004). During this interval, successive floods through the distributary channels produced frontal and lateral fan lobes which coalesced to form a fringe of amalgamated sandstone bodies resulting in a continuous sandy belt that prograded and retrograded in a N-S direction (Fig. 3). The gradual, vertical transition from Unit 2 to Unit 3 (forming a medium-scale coarsening-upward trend) indicates the southward progradation of the terminal lobe onto previous mudflat and shallow lacustrine areas.

Lateral to the sheet sandstone facies (between logs J and K, Fig. 11A), anomalously deep incised channel deposits (up to $1.2 \mathrm{~m}$ thick) occur in the upper part of Unit 3 . These channels suggest local incision because of minor lake-level falls as in the Súria-Cardona system described above (facies S2a).

Unit 4 (lower Torà Fm.) is composed of yellow to brown mudstones (facies M3), grey sheet-like sandstones (facies S5) and channel-like sandstones (facies S4) arranged in coarsening-upward, prograding delta sequences $1 \cdot 3-3.5 \mathrm{~m}$ thick (Fig. 7A). In contrast to the terminal lobe facies, these deposits are barren of trace fossils. These sequences succeed one another and are up to $4 \mathrm{~km}$ wide. The vertical transition between red terminal lobe facies of Unit 3 to lacustrine facies of Unit 4 is sharp, pointing to a rapid lacustrine transgression-expansion facilitated by the gentle gradient of the distal fan.

Unit 5 (upper Torà Fm.) consists of white carbonate siltstones and grey marly mudstones which display a variable carbonate content (facies St). The siltstones display fine lamination, interbedded stromatolitic horizons (Fig. 7B), lenticular gypsum casts (Fig. 7C) and lenticular bedding of very fine sandstones. All these features indicate shallow lacustrine deposition (facies association CL). Sandstone bodies at the base of the unit record the transition of the deltaic sequences to lacustrine deposits.

Above Unit 5, poorer outcrops prevented detailed tracing of the succession. Nevertheless, isolated exposures suggest the occurrence of sandstone-dominated deltaic facies, similar to those described in Unit 4, in transition to the fluvial facies of Solsona Fm. These nearshore deposits indicate the last regressive phase of the lacustrine system in the Sanaüja area.

Overall, the correlation panel (Fig. 11A) clearly documents a regressive-transgressive cycle characterized by the vertical stacking of: (i) evaporitic playa-lake gypsum (Unit 1); (ii) mudflat mudstones (Unit 2); (iii) NCTL sandstones (Unit 3); (iv) deltaic lacustrine deposits (Unit 4); and (v) offshore lacustrine carbonate siltstones (Unit 5), the latter two resulting from the expansion of the basin centre lacustrine system. This sequential arrangement indicates palaeoenvironmental changes that occurred in the transition from the low-gradient distal fluvial fan to the shallow lacustrine systems in the Sanaüja area during a major phase of lacustrine expansion and/or deepening. In addition, during this phase the lacustrine system showed marked changes in salinity, water chemistry (chloride-sulphate to carbonatedominated) and water depth (from playa environments to lakes several metres deep, allowing the development of marginal deltaic environments). These data also imply that the water depth of the lacustrine environment, where the distal-alluvial sandy sediments were deposited, was critical to the development of either terminal lobe or deltaic environments.

\section{DISCUSSION}

\section{Controls on the sedimentary architecture of the distal fan deposits}

The analysis of the facies changes and the sequential arrangement of the distal fluvial fan deposits and their relationship with the coeval lacustrine systems can reveal important information on tectonic, climatic and sedimentary processes (Keighley et al., 2003; Leier et al., 2005). In the Ebro Basin, the facies assemblage and architectural style of the transition between distal alluvial systems and lacustrine settings reflects the balance between: (i) the aggradation/progradation of fans; and (ii) changes in lake level. The former is a function of subsidence rates, thrusting at the mountain front and trunk river avulsion on the fans, and determines the large-scale sequential arrangement. The latter is climatically forced and may also reflect drainage changes in the hinterland. Lake-level changes impact on the 
kind of alluvial-lacustrine transition in distal fluvial fan settings (see below).

The major tectonic control on fluvial fan accumulation was activity on the $\mathrm{E}-\mathrm{W}$ orientated Pyrenean front, where the catchment basin and drainage network feeding the two Palaeogene fluvial fan systems of the eastern Ebro Basin were located. The positions of the main source areas were linked to transverse and oblique structures, and probably correspond to the precursors of the modern Cardener and Llobregat river valleys (Fig. 1B). A similar arrangement occurs in the south-central Pyrenees with the Cinca, Alcanadre and Noguera Ribagorçana rivers (Hirst \& Nichols, 1986; Jones, 2004).

The catchment basins in the eastern Pyrenees grew synchronously as the orogenic wedge grew and advanced to the south. Basinward advance of the fans was probably linked to thrust propagation in addition to expansion of the source area which would have included significant river capture. The basinward progradation of the fan systems resulted in an overall coarseningupwards megasequence spanning c 2 Myr (Anadón et al., 1989). The three alluvial-lacustrine intervals of the central sequence in the Sanaiija area, and the intermediate-scale sequences in the Súria-Cardona area, correspond to progradational-retrogradational pulses set within the overall coarsening-upwards progradational megasequence. In this tectonically active setting, climate variations would have exerted an important control on the sedimentary architecture at a smaller scale. Nevertheless, it is difficult to isolate climate forcing at the scale of the intermediate to minor scale cycles without more precise age control, and in the absence of palaebiological and/or geochemical proxies. It is likely that the intermediate scale facies arrangement was determined by a combination of climate, tectonics and autocyclic processes.

Differences in subsidence rates also influenced the facies changes and the sequential arrangement of the distal fluvial fan deposits and their relationship with coeval lacustrine systems. Relatively low subsidence rates in the Cardona-Súria area favoured shallow lakes and, consequently, distal fluvial fan environments were characterized by terminal lobe facies. Relatively high subsidence rates in the Solsona-Sana ïja area favoured lake-level fluctuations and periods with more persistent deeper lakes that promoted distal delta formation.

The absence of well-developed non-hydromorphic palaeosols and aeolian deposits in the studied sequences, although they are common in similar modern alluvial-lacustrine settings (e.g. Croke et al., 1996), is consistent with high sediment accumulation rates. The lack of a well developed aeolian component may also reflect a relatively humid climate, given the palaeo-latitudinal position of the Ebro Basin at the time of deposition. Repeated reworking by streams and waves of the aeolian deposits, if formed, could explain their low preservation (Hinds et al., 2004).

\section{Alluvial-lacustrine transitions in distal fluvial fan settings}

In the Ebro Basin, repeated vertical and lateral facies changes within the Palaeogene distal fan record reflect the high sensitivity of these palaeoenvironments to changes in sediment supply, water flux, subsidence rate and base level. The sensitivity reflects: (i) the low gradient of the depositional surface where the alluvial and lacustrine deposits accumulated; and (ii) the shallow and oscillating water table and lake level. The changes in the transition style between the distal fluvial fan deposits and the basin centre lacustrine deposits can be explained by the alternation of lowstand and highstand phases in the lake.

\section{Low lake level}

At times of low lake-level (Fig. 12), mudflats characterized by dry surfaces and isolated ponds were well developed in the distal fringes of the fluvial fans. Where the water and sediment input from the fluvial fans increased, the mudflats were replaced by advancing terminal lobe environments, as is evident in the sections at Cardona, Súria and Sanaiija. In these cases, progradation of terminal lobes occurred in front of numerous loworder distributary channels resulting in a continuous sandy fringe of coalesced lobe elements (Fig. 3). The location of this fringe was determined by the size and shape of the fluvial fan systems, mainly a function of basin subsidence and sediment supply to the fan. Accommodation for individual sandy lobes was locally controlled by the location of the fore deep zone and by the topography generated by the distribution of previous lobe deposits at the fan margin.

The thin bedded sandstone deposits which dominate the sandy part of the terminal lobes (NCTL f. a.) are interpreted to have been generated by streams entering either: (i) an existing lowstand shallow lake; or (ii) ephemeral short- 


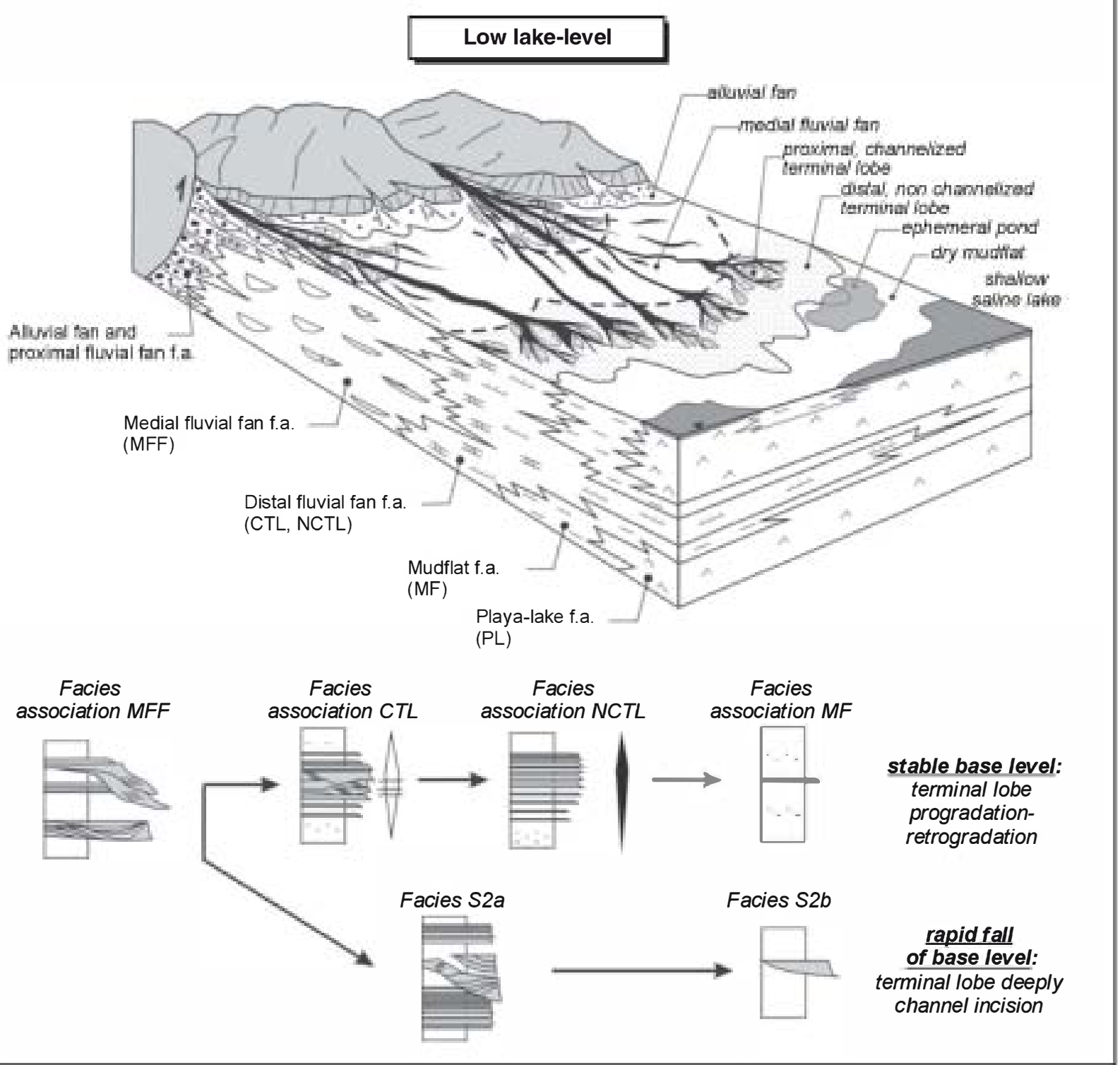

Fig. 12. Lateral relationship between the diverse clastic facies in the distal fluvial fan fringe of the Palaeogene eastern Ebro Basin. Medial fluvial fan areas are to the left, distal areas are to the right. Low lake-level scenario: fluvial fan channels spread out on a mudflat surface forming terminal lobes and its deposits coalesce to form a continuous sandy fringe in distal fan area. The reconstruction is constrained mainly by observations in the Súria-Cardona fan deposits and incorporates a stable base-level phase and a rapid fall of base level which produced deep channel incision (facies 2a and 2b).

lived ponds formed on commonly dry, nonvegetated mudflats by water discharged or supplied in the same flooding event that contributed the sand. In both cases, when the channelized flood entered the water body, the density contrast between the incoming flow and the receiving water body produced a turbidite hyperpycnal flow. Flow expansion from stream mouths can result in sandy lobes hundreds of metres in width. The suspended load supplied in each flood settled rapidly in the lobe and inter-lobe areas. In the shallow sub-aqueous settings, surface waves formed wave ripples. The total or partial sub-aerial exposure of the sand lobes was caused by the subsequent evaporation and infiltration of the water. This could have led to partial erosion and reworking of the sediment by subsequent processes such as wind, animal and plant activity. However, in the studied case, the water table probably remained relatively high (i.e. centimetres to tens of centimetres beneath the surface), as is demonstrated by the preservation of 
bird and mammal tracks and other trace fossils such as Thaenidium, but without evidence of significant vegetation.

Temporary lake-level drops may have produced incision of the drainage network in the distal fan which consequently influenced the distribution of subsequent sand accumulations along the fan margin. These lake-level drops are recognized by the presence of isolated ribbon-like channels, anomalously deeply incised in the lobe and mudflat deposits, at the same stratigraphic position in different sites (i.e. $10 \mathrm{~m}$ above key bed 8 in North Súria and West Súria cross sections, Figs 8 and 9). Nevertheless, because of a lack of continuous N-S outcrops, it is not possible to recognize which incised channels splay out to form which distal sheet deposits. In any case, the scarcity of deeply incised channels suggest that lake-level falls were probably not the main mechanism whereby the terminal lobes prograded.

\section{High lake level}

During stable, relatively deep lacustrine conditions (probably linked to a wet phase), floods from the fluvial channels built fluvial-dominated deltas at the lake shoreline (Fig. 13). As in the case of the terminal lobes, hyperpycnal flows dominated transport and deposition, forming deltaic mouth bars. The absence of littoral currents and weak wave action in the shallow nearshore areas of the lacustrine system prevented lateral re-distribution of sand, thus explaining the lack of continuous sandy shorelines (beaches) and shorefaces. Terminal lobe deposits that are sharply overlain

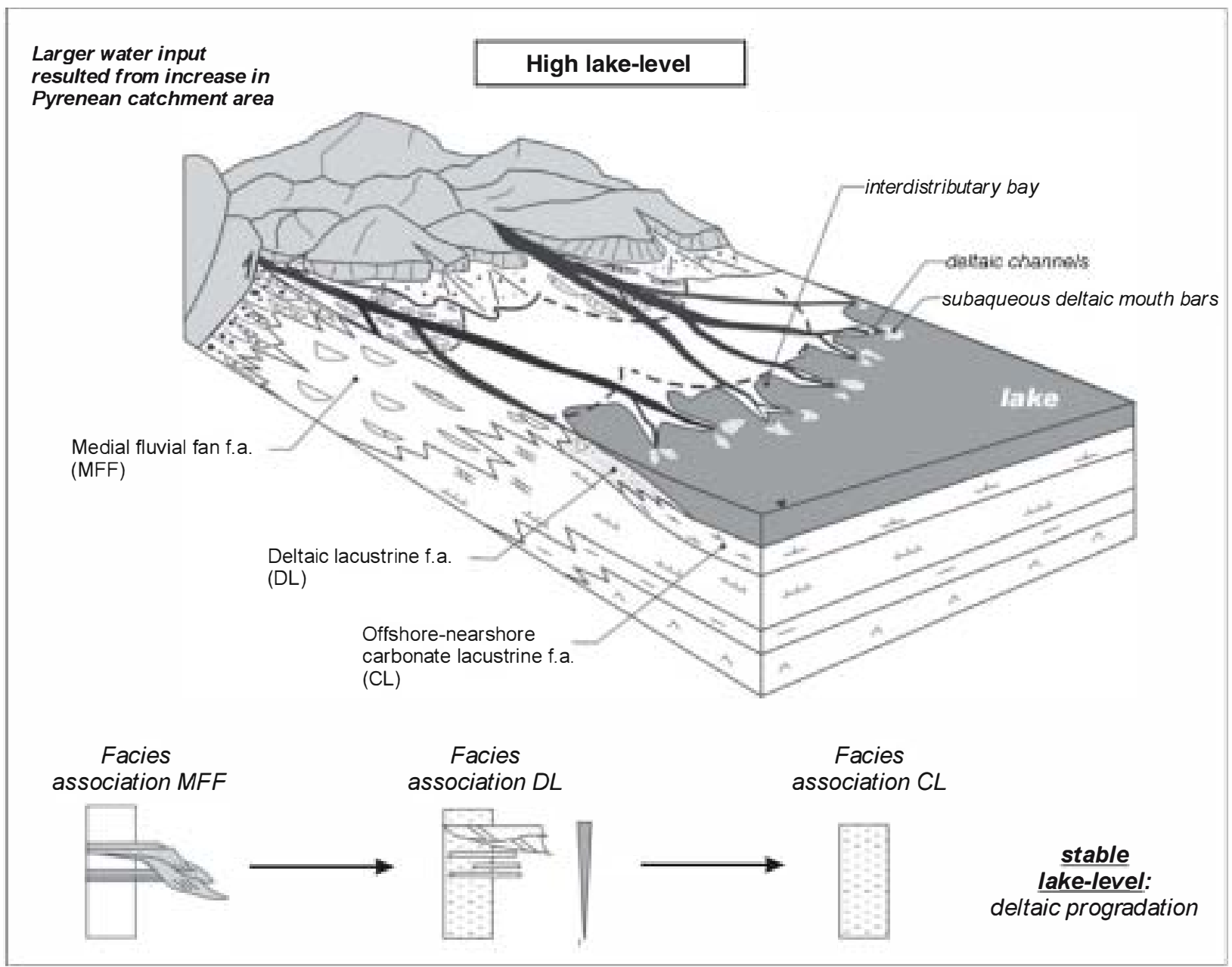

Fig. 13. Lateral relationship between the diverse clastic facies in the distal fluvial fan fringe of the Palaeogene eastern Ebro Basin. Relatively proximal areas (medial fluvial fan) are to the left, distal areas are to the right. High lakelevel scenario: medial fluvial fan channels advanced into a lake forming deltas at the shoreline. The sandy deltaic facies locally formed in restricted shoreline zones at the termini of the active channels are separated from one another by muddy interdistributary bay deposits This scenario is constrained mainly by observations in the Sanaüja succession and corresponds to a stable phase of high lake-level favouring delta progradation. 
by deltaic facies suggest that the lake water rose rapidly.

The onset of delta progradation recorded in the Solsona-Sana üja fluvial fan system was associated with lake-level changes. During phases of lake-level expansion and stabilization, the deltas prograded. Rapid lake-level rises displaced the shoreline up to several kilometres northwards (Fig. 11A) and during the subsequent lake-level stabilization phase, shoreline accommodation was filled by a new delta-progradation cycle. In the Sanaiija succession, the vertical transition from terminal lobe facies to offshore lacustrine facies is characterized by littoral deposits which are arranged in five deltaic progradational cycles (Fig. 10) suggesting that significant lake expansion occurred in discrete pulses.

Deltaic deposits formed locally in front of major fluvial fan channels during high lake-level conditions and were laterally separated from one another by muddy interdistributary bay deposits.

The lake depth during lake highstands was critical to the formation of deltas on the shoreline. When the water was less than about $1.3 \mathrm{~m}$ deep (the minimum thickness of the observed deltaic progradational sequences) sub-aqueous terminal lobes formed in front of the distributary channels. This is supported by the common occurrence of exposure indicators on top of the lobes, whereas such features are absent in the deltaic mouth bar deposits. The absence of deltaic deposits in the fringe of the Cardona-Súria Fan probably reflects less persistent and shallower lacustrine conditions in this area compared with the distal part of the adjacent the Solsona-Sanaiija Fan.

\section{CONCLUSIONS}

1 Two Palaeogene fluvial fan (megafan) systems linked to the Pyrenean front are recognized in the eastern Ebro Basin. The Cardona-Súria and Solsona-Sanaïja fluvial fans were 40 and $35 \mathrm{~km}$ in radius and 800 and $600 \mathrm{~km}^{2}$ in area respectively. They were fed by large drainage areas which exploited transverse structures along the main south-Pyrenean thrust (probably related to the modern Cardener and Llobregat river valleys). During the Priabonian to the middle Rupelian, the fluvial fan systems advanced into a hydrologically closed foreland basin, and shallow lacustrine systems persisted in the basin centre.

2 The Cardona-Súria and Solsona-Sanaiija fluvial fans both form an overall upward-coarsening megasequence ( $>\mathbf{8 0 0} \mathrm{m}$ thick) that in- cludes medial and distal fluvial fan, mudflat, and playa-lake facies. This upward-coarsening megasequence is linked to an increase of the drainage areas through time and the southward advance of Pyrenean front.

3 A near longitudinal N-S, $10 \mathrm{~km}$ long, correlated section between the Cardona and Súria areas shows a marked lateral facies change from fluvial-dominated, medial-fan deposits (Solsona Fm.) to mudflat and terminal lobe deposits (Súria Fm.). A transverse, continuous W-E cross section, $5 \mathrm{~km}$ long, in the Sanaiija area shows rapid lateral facies changes between evaporitic playalake, mudflat, terminal lobe, deltaic and carbonate-rich lacustrine deposits. Facies analysis of the sequences from both correlation panels identifies two styles of alluvial-lacustrine transition and these are related to lake-level conditions and the subsidence rate in distal fan areas. In the Cardona-Súria Fan, relatively low subsidence rates favoured dominantly shallow and ephemeral lake conditions and, consequently, distal fluvial fan environments were characterized by terminal lobe facies. In the Solsona-Sanaiija Fan, higher subsidence rates favoured lake-level fluctuations and periods of more persistent high lake-level conditions. Consequently the alluviallacustrine transition was characterized by alternations between fluvial-dominated delta deposits (separated by interdistributary muds) during highstands, and terminal lobe deposits during lowstands.

4 Sandy terminal lobes are arranged in intermediate scale, coarsening-fining-upward sequences (up to $20 \mathrm{~m}$ thick) associated with mudflat facies. The progradational character of the terminal lobes was controlled by a combination of tectonic, climatic and fan channel avulsion processes. The sandy lobes are made-up of the deposits of density underflows into ephemeral standing bodies of water that formed and onlapped the fan toes during and immediately following flood events in distal fluvial fan areas. The sedimentary structures and trace fossils indicate that the lobe deposits were formed by quasi-steady hyperpycnal turbidity currents which were followed by a rapid sub-aerial exposure.

5 Coarsening-upwards sequences (up to $3.5 \mathrm{~m}$ thick) overlying offshore lacustrine facies characterize the progradational deltaic deposits. Finegrained offshore lacustrine and prodelta deposits are overlain by sandy mouth bar and feederchannel deposits reflecting progradation of fluvial fan channel mouths. Distal mouth bar deposits have a frictional character and were formed by 
similar hyperpycnal processes as the terminal lobes but resulted in less extensive sandbodies, restricted palaeocurrent dispersions and lack of emersion features.

6 Minor (metres to tens of metres in thickness) terminal lobe cycles were probably controlled by climatic oscillations and autocyclic sedimentary processes such as channel avulsions or lobe switching, and by lateral compensation on the low-gradient distal fan surface. During relatively wet periods, the terminal lobes prograded onto the shallow lacustrine and mudflat areas resulting in coarsening-upward sequences, consisting of mudstone, tabular sandstones and channelized sandstones. During the relatively dry periods, the terminal lobes experienced retrogradation and generated fining-upward sequences that overlie the previously accumulated coarsening-upward cycles. The presence of relatively deeply incised distributary channels associated with distal terminal lobe facies of the Cardona-Súria system indicates rapid lake-level falls.

7 The internal stacking of the deltaic deposits (in cycles several metres thick) formed during lake high-stand conditions and are attributed to minor lake-level oscillations. During periods of lake-level stabilization, normal deltaic progradation produced coarsening-upward sequences. The thinnest progradational sequence, $1.3 \mathrm{~m}$ thick, is a proxy for the minimum depth for the lake water into which the deltas prograded. The sandy deltaic facies formed in restricted shoreline zones at the termini of the active channels and are separated from one another by muddy interdistributary bay deposits. In contrast, the terminal lobe sheets expanded from a series of mid-fan intersection points and coalesce to form a continuous sandy fringe wrapping around the distal fan.

\section{ACKNOWLEDGEMENTS}

This research was funded by Shell International Exploration and Production B.V., through a cooperative project with the University of Barcelona (Fundació Bosch i Gimpera, project 301737). Financial support was also provided by the Spanish Ministry of Research and Education as a contribution to the CICYT project BTE20013650. We would thank to Jordi M. de Gibert for his comments on the trace fossils. We have benefited from comments and fruitful discussions with Miguel López-Blanco and Luis Cabrera. Thanks are also due to Stuart Jones and Gary Nichols for their constructive reviews on earlier draft of this manuscript as well as the editor Peter Haughton for the numerous suggestions and comments that helped to improve the manuscript. The authors would like to express their gratitude to Shell International Exploration and Production B.V. for giving permission to publish this work.

\section{REFERENCES}

Abdullatif, O.M. (1989) Channel-fill and sheet-flood facies sequences in the ephemeral terminal River Gash, Kassala, Sudan. Sed. Geol., 63, 171-184.

Allen, P.A. and Mange-Rajetzky, M. (1982) Sediment dispersal and palaeehydraulics of ligecene rivers in the eastern Ebr• Basin. Sediment•l•gy, 29, 705-716.

Anadón, P., Cabrera, L., Guimerà, J. and Santanach, P. (1985) Strike-slip deformation and sedimentation along the SE margin of Ebr• Basin. In: Strike-Slip Deformation, Basin Formation and Sedimentation (Eds K.T. Biddle and N. Christie-Blick), SEPM Spec. Publ., 37, 303-318.

Anadón, P., Cabrera, L., Colombe, F., Marze, M. and Riba, $\bullet$. (1986) Syntectonic intraformational unconformities in alluvial fan deposits Eastern Ebr• Basin margins (SE Spain). In: Foreland Basins (Eds P.A. Allen and P. Hømewood), IAS Spec. Publ., 8, 259-271.

Anadón, P., Cabrera, L., Celldeforns, B. and Sáez, A. (1989)

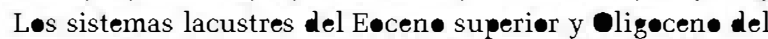

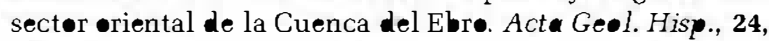
205-230.

Anadón, P., Cabrera, L., Chøi, S.J., Celembe, F., Feist, M. and Sáez, A. (1992) Biøzønación del Paléogen c continental de la zona oriental de la Cuenca del Ebrø mediante carófitas: implicaciones en la biozønación general de carófitas de Eurøpa Occidental. Acta Ge•l. Hisp., 27, 69-94.

Arenas, C. and Parde, G. (1999) Latest ligecene-Late Micene Lacustrine systems of the nøth-central part of the Ebr Basin (Spain): sedimentary facies model and palaenge-

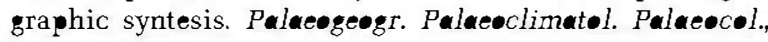
151, 127-148.

Blair, T.C. and McPhersen, J.G. (1994) Alluvial fans and their natural distintion from rivers based on møphøløgy, hydraulic precesses, sedimentary precesses, and facies assemblages. J. Sed. Res., 59, 450-489.

Brierley, G.J., Fergusen, R.J. and Wollfe, K.J. (1997) What is a fluvial levee? Sed. Geol., 114, 1-9.

Buatıis, L.A. and Mánganø, M.G. (1995) The paleøenvirønmental and paleeeceløgical significance of the lacustrine Mermia ichnofacies: an archetypical subaque»us n七nmarine trace f $\bullet s i l$ assemblage. Ichn $\bullet$, 4, 151-161.

Buatøis, L.A. and Mánganø, M.G. (1998) Trace føssil analysis -f lacustrine facies basins. Palaengeogr. Palaeoclimatel. Paluevel., 140, 367-382.

Cabrera, L. (1983) Estratigrafía y sedimentøløgía de las førm-

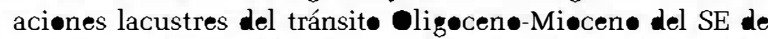
la Cuenca del Er $\bullet \mathrm{PhD}$ thesis, University of Barceløna, Barceløna, Spain, 443 pp.

Cabrera, L. and Sáez, A. (1987) Cøal depesition in carbonate rich shalløw Lacustrine systems: the Calaf and Mequinenza sequences (Oligecene, Eastern Ebr• Basin, NE Spain).

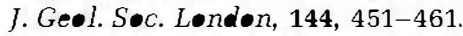

Cavagnette, C. and Anadón, P. (1996) Preliminary palynıløgical investigations on fleristic and climatic change in the 


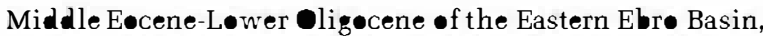
north-east Spain. Rev. Palaeøbot. Palyn 1., 92, 281-305.

Collinsen, J.D. (1996) Alluvial sediments. In: Sedimentary Environtments and Facies (Ed. H.G. Reading) 3rd edn, pe. 37-82. Science, Oxf r r.

Croke, J., Magee, J. and Price, D. (1996) Majør episødes of Quaternary activitiy in the lower Neales River, norhwest of Lake Eyre, central Australia. Palaengeogr. Palaeoclimatel. Palaeocol., 124, 1-15.

DeCelles, P.G. and Cavazza, W. (1999) A cœmparisøn of fluvial megafans in the Cordilleran (upper Cretaceous) and modern

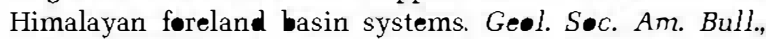
111, 1315-1334.

DeCelles, P.G. and Giles, K.A. (1996) Føreland basin systems. Busin Res., 94, 3851-3866.

Del Sante, G., García-Sansegundo, J., Sarasa, L. and Torrebadella, J. (2000) Estratigrafía y estructura del Terciariø en

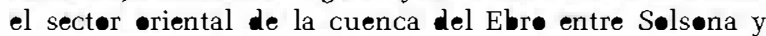
Manresa (NE de España). Rev. S•c. Ge•l. Esp., 13, 265-278.

Farquharsøn, G.W. (1982) Lacustrine deltas in a Mesøuic alluvial sequence from Camp Hill, Antarctica. Sedimentøl-gy, 29, 717-725.

Friend, P.F. (1978) Distintive features of søme ancient river systems. In: Fluvial Sediment•logy (Ed. A.D. Miall), Mem. Can. S•c. Petrel. Ge•l., 5, 531-543.

Genise, J.F., Mangane, M.G., Buatois, L.A., Laza, J.H. and Verde, M. (2000) Insect trace fossil asseciations in Paleosøls: the cœrinisphaera ichnøacies. Palaiøs, 15, 49-64.

George, G.T. and Berry, J.K. (1993) A new litheestratigraphy and depositional model for the Upper Rotliegend of the UK sector od the søuthern North Sea. In: Characterizations -f Fluvial and Aeolian Reservoirs (Eds C.P. North and

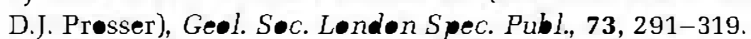

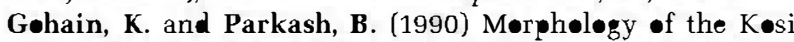
Megafan. In: Alluvial Fans: A Field Approach (Eds A.H.

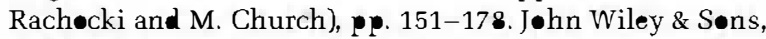
Chichester.

Hardie, L.A., Smoot, J.P. and Eugster, H.P. (1978) Saline lakes and their deposits: a sedimentølogical approach. In: Mødern and Ancient Lake Sediments (Eds A. Matter and M.E. Tuckjer), IAS S pec. Publ., 2, 7-41.

Hasiøtis, S.T. (2002) Continental trace fossils. SEPM Shørt Cøurse Nøtes, 51, 132 p.

Hasiøtis, S.T. (2003) Cømplex ichnøf ssils and sølitary and

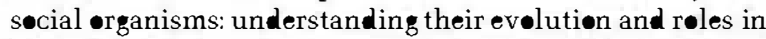
terrestial paleøecosystems. Palaengeogr. Palaeoclimatel. Palue $01 ., 192,259-320$.

Hinds, D.J., Aliyeva, E., Allen, M.B., Davies, C.E., Kroonenberg, S.B., Simmens, M.D. and Vincent, S.J. (2004) Sedimentation in a discharge dominated fluviallacustrine system: the Nengene Productive Series of the South Caspian Basin, Azerbaija. Mar. Petrel. Geøl., 21, 613-638.

Hirst, J.P.P. and Nichøls, G.J. (1986) Thrust tectøic contrøls -n alluvial sedimentation patterns, southern Pyrenees. In: Foreland Basins (Eds P.A. Allen and P. Hømeweod), IAS Spec. Publ., 8, 153-164.

Hornung, J. and Aigner, T. (2002a) Reserv terminal alluvial plain: an øutcrøp analøgue study (Upper Triassic, Søuthern Germany). Part I. Sedimentøløgy and petrøphysics. J. Petr•l. Ge•l., 25, 3-30.

Hornung, J. and Aigner, T. (2002b) Reservoir architecture in a terminal alluvial plain: an øutcrøp analøgue study (Upper Triassic, Søuthern Germany). Part II. Ciclicity, contrøls and models. J. Petr•l. Ge•l., 25, 151-178.
Horten, B.K. and DeCelles, P.G. (2001) Modern and ancient fluvial megafans in the foreland basin system of the central Andes, søuthern Bølivia: implicatiøns f drainage network evolution in føld trust belts. Basin Res., 13, 43-63.

Høvius, N. (1996) Regular spacing •f drainage •utlets frøm linear mountain belts. Basin Res., 8, 29-44.

Hsii, K.J. and Siegenthaler, C. (1969) Preliminary experiments -n hydrodinamic movement induced by evaporation and their bearing on the dolømite prøblem. Sediment॰logy, 12, 11-25.

Hubert, J.F. and Hyde, M.G. (1982) Sheet-fløw deposits of graded beds and mudstones on a alluvial sandflat-playa system: Upper Triassic Blømidon redbeds, St Mary's Bay,

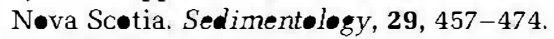

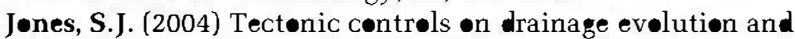
development of terminal alluvial fans, søuthern Pyrenees, Spain. Terra Nøva, 16, 121-127.

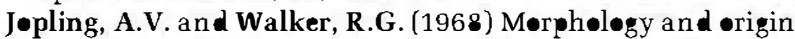
of ripple-drift cross-lamination, with examples from the Pleistecene of Massachusetts. J. Sed. Petr॰l., 38, 971-984.

Keighley, D., Flint, S., Howell, J. and Moscarielle, A. (2003) Sequence stratigraphy in lacustrine basins: a medel før part -f the Green River Formation (Eøcene), søuthwest Uinta Basin, Utah, USA. J. Sed. Res., 73, 987-1006.

Kelly, S.B. (1993) Cyclical discharge variations recerded in alluvial sediments: an example frøm Devønian of søuthwest Ireland. In: Characterizations of Fluvial and Aeolian Reservøirs (Eds C.P. Nørth and D.J. Prøsser), Spec. Publ. Geøl.

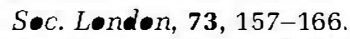

Kelly, S.B. and Olsen, H. (1993) Terminal fans - a review with reference t• Devønian examples. Sed. Ge•l., 85, 339-374.

Lanaja, J.M. (1987) Contribución de la exploración petrolifera al conocimient• de la geologia de España. IGME, Madrid, 456 p.

Lang, S.C., Payenberg, T.H.D., Reilly, M.R.W., Hicks, T., Bensen, J. and Kassan, J. (2004) Mødern analøgues før dryland sandy fluvial-lacustrine deltas and terminal splay

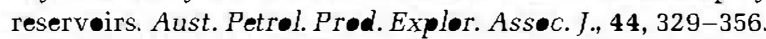

Leier, A.L., De Celles, P.G. and Pelletier, J.D. (2005) Møuntains, monseens, and megafans. Geology, 33, 289-292.

López-Blance, M. (2002) Sedimentary respense to thrusting and fold growing on the SE margin of the Ebro basin (Paleøgene, NE Spain). Sed. Geel., 146, 133-154.

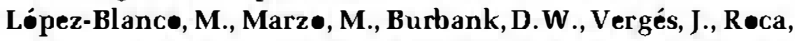
E., Anadón, P. and Piña, J. (2000) Tectonic and climatic contrøls on the development of large foreland fan deltas: Møntserrat and Sant Llørenç del Munt systems (Middle

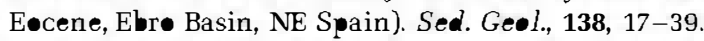

Luzón, A. (2005) Oligøcene-Miøcene alluvial sedimentation

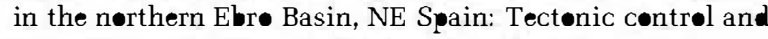
palaeøgeøgraphical evølutiøn. Sed. Ge•l., 177, 19-39.

Luzón, A., González, A., Muñoz, A. and Sánchez-Valverde, B. (2002) Upper Oligecene-Løver Miøcene shalløwingupward lacustrine sequences controlled by periedic and

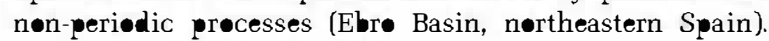
J. Paleolimn 1., 28, 441-456.

Mack, G.H., Løve, D.W. and Seager, W.R. (1997) Spilløver models for axial rivers in regions of continental extension: the Rí Mimbres and Rí Grande in the søuthern Rí Grande rift. USA. Sediment•logy, 44, 637-652.

Magee, J.W., Bewler, J.M., Miller, G.H. and Williams, D.L.G.

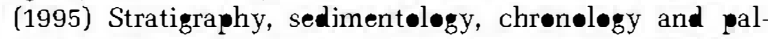
aeڤhydroløg of Quaternary lacustrine deposits at Madigan Gulf, Lake Eyre, Søuth Australia. Palaengengr. Palaeoclimatel. Palaevecl., 113, 3-42. 
Malmsheimer, K.W., Mensink, H. and Brinkenann, R. (1979) Der geøløgishe Aufbau des Zentralkatalanischen Mølassebeckens. Geol. Rundschau, 68, 121-162.

Moscariellø, A. (2005) Exploration potential of the mature Søuthern Nørth Sea Basin margins: søme unconventional plays based on alluvial and fluvial fan sedimentation models. In: Petroleum Geology: North-West Eurøpe and Global Perspectives - Proceedings of the Sixth Petroleum Geology Conference (Eds A.G. Dore and B. Vining), pp. 595-

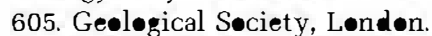

Mukerji, A.B. (1976) Terminal fans of inland streams in SutlejYamuna Plain, India. Zeitschr. Geømøph•l. N. F., 20, 190204.

Mulder, T. an Alexander, J. (2001) The physical character of subaqueous sedimentary density flews and their deposits. Sediment•løgy, 48, 269-299.

Mulder, T., Syvitski, J., Migeon, S., Faugères, J.C. and Savøye, B. (2003) Marine hyperpycnal fløws: initiation, behaviør and related deposits. Mar. Petrøl. Ge•l., 20, 861882.

Muñøz, J.A. (1992) Evølution of a continental cøllisiøn belt: ECORS-Pyrenees crustal balanced section. In: Thrust Tectønics (Ed. K.R. McClay), p. 235-246. Chapman \& Hall, Londen.

Newell, A.J., Tverdekhlebov, C.P. and Benten, M.J. (1999) Interplay of tectonics and climate on a transverse fluvial system. Upper Permian, Søuthern Uralian Føreland Basin, Russia. Sed. Geel., 127, 11-29.

Nichols, G.J. and Hirst, J.P.P. (1998) Alluvial fans and

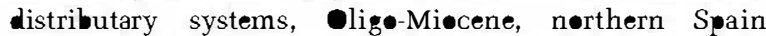
contrasting processes and products. J. Sed. Res., 68, 879889.

Nichøls, G. and Thømpsøn, B. (2005) Bedrøck lithøløgy cøn-

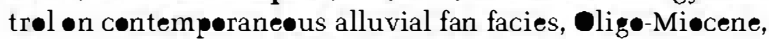
søuthern Pyrenees, Spain. Sedimentology, 52, 571-585.

Parkash, B., Awasthi, A.K. and Gøhain, K. (1983) Lithøacies of the Markanda terminal fan, Kurukshetra district, Haryana, India. In: Modem and Ancient Fluvial Systems (Eds J.D. Cøllinsøn and J. Lewin), IAS Spec. Publ., 6, 337-344.

Riba, - (1976) Syntectøic uncønformities of the Alt Cardener, Spanish Pyrenees: a genetic interpretation. Sed. Ge•l., 15, 213-233.

Sadler, S.P. and Kelly, S.B. (1993) Fluvial processes and cyclicity in terminal fan deposits: an example from Late

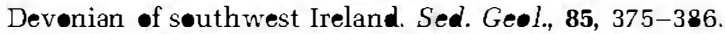

Sáez, A. (1987) Estratigrafia y sedimentologia de las formaci-

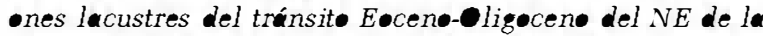
Cuenca del Ebre. PhD Thesis, University of Barceløna. In:
Cøllecciø Tesis Doctorals Microfitxades, Publ. U. de Barceløna, $31 \mathbf{8} \mathbf{p p}$.

Salvany, J.M. (1997) Continental Evaporitic Sedimentation in

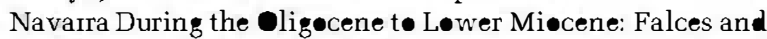
Lerín Formations. In: Sedimentury Deposition in Rift and Foreland Basins (Paleogene and Lower Neogene) (Eds G. Bussø and C. Schreiber), pe. 397-419. Cølumbia University Press, New York.

Shukla, U.K., Singh, I.B., Sharma, M. and Sharma, S. (2001) A mødel of alluvial megafan sedimentatiøn: Ganga Megafan. Sed. Geol., 144, 243-262.

Sneh, A. (1983) Desert stream sequences in the Sinai Peninsula. J. Sed. Petrol., 53, 1271-1279.

Sølé, N. and de Porta, J. (1982) Contribución a la palinøløgía

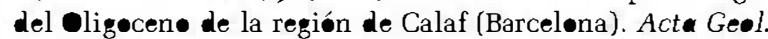
Hisp., 14, 351-353.

Tø»th, S. (1999a) Fløedøuts in Central Australia. In: Varieties -f Fluvial Form (Eds A.J. Miller and A. Gupta), pe. 219-247. Wiley \& Søns, Lenden.

Tøoth, S. (1999b) Døwnstream changes in fløodplain character -n the Northern Plains of arid central Australia. In: Fluvial Sediment•løgy VI (Eds N.D. Smith and J. Røgers), I AS S pec. Publ., 28, 93-112.

Tunbridge, I.P. (1984) Facies medel for a sandy ephemeral stream and clay playa complex; the Middle Devonian

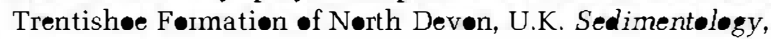
21, 697-715.

Vergés, J., Marzø, M. and Muñøz, J.A. (2002) Grøwth strata in foreland basins. Sed. Ged., 146, 1-9.

Williams, E.A., Ford, M., Vergés, J. and Artoni, A. (1998) Alluvial gravel sedimentation in a contractional grøwth føld setting, Sant Llørenç de Mørunys, søutheastern Pyrenees. In: Cenozøic Foreland Basins of Western Eurøpe (Eds M. Mascle, C. Puigdefàbregas, M. Luterbacher and

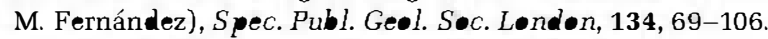

Yuste, A., Luzón, A. and Bauluz, B. (2004) Prøvenance of -ligecene-Miøcene alluvial and fluvial fans of the nørthern Ebr Basin (NE Spain): an XRD, petrøgraphic and SEM study. Sed. Ge•l., 172, 251-268.

Zavala, C., Ponce, J.J., Arcuri, M., Drittanti, D., Freije, H. and Asencie, M. (2006) Ancient lacustrine hyperpycnites: a depositional model from a case study in the Ray mation (Cretaceœus) of west-central Argentina. J. Sed. Res., 76, 41-59. 